\title{
A Less Evaluative Measure of Big Five Personality: Comparison of Structure and Criterion Validity
}

\author{
Joshua K. Wood, Jeromy Anglim, Sharon Horwood \\ ${ }^{1}$ School of Psychology, Deakin University, Australia
}

\begin{abstract}
Researchers and practitioners have long been concerned about detrimental effects of socially desirable responding on the structure and criterion validity of personality assessments. The current research examined the effect of reducing evaluative item content of a Big Five personality assessment on test structure and criterion validity. We developed a new public domain measure of the Big Five called the Less Evaluative Five Factor Inventory (LEFFI), adapted from the standard 50-item IPIP NEO, and intended to be less evaluative. Participants ( $n$ $=3,164)$ then completed standard (IPIP) and neutralized (LEFFI) measures of personality. Criteria were also collected, including academic grades, age, sex, smoking, alcohol consumption, exercise, protesting, religious worship, music preferences, dental hygiene, blood donation, other-rated communication styles, other-rated HEXACO personality, and cognitive ability (ICAR). Evaluativeness of items was reduced in the neutralized measure. Cronbach's alpha and test-retest reliability were maintained. Correlations between the Big Five were reduced in the neutralized measure and criterion validity was similar or slightly reduced in the neutralized measure. The large sample size and use of objective criteria extends past research. The study also contributes to debates about whether the general factor of personality and agreement with socially desirable content reflect substance or bias.

Keywords: personality, social desirability, Big Five, general factor of personality, faking, halo
\end{abstract}

\section{A Less Evaluative Measure of Big Five Personality: Comparison of Structure and Criterion Validity}

Researchers and practitioners have long endeavored to understand and counter the detrimental effects of socially desirable responding bias on the structure (Saucier, 2002; Schmit \& Ryan, 1993; Zickar \& Robie, 1999) and criterion validity of personality assessments (Douglas, McDaniel, \& Snell, 1996; Jeong, Christiansen, Robie, Kung, \& Kinney, 2017; Morgeson et al., 2007; Rothstein \& Goffin, 2006; Tett, Jackson, \& Rothstein, 1991; Topping \& O'Gorman, 1997). Similarly, debates about whether agreement with socially desirable items reflects substance or bias can be seen in multiple personality literatures including discussion of impression management scales (de Vries, Zettler, \& Hilbig, 2014; Nederhof, 1985; Paulhus,

\footnotetext{
${ }^{1}$ Citation (check publisher for updated year, volume, and page numbers):

Wood, J., Anglim, J., \& Horwood, S. (2021). A less evaluative measure of big five personality: Comparison of structure and criterion validity. European Journal of Personality. https://doi.org/10.1177/08902070211012920

Data is available on the OSF at: https://osf.io/kfz28 Correspondence concerning this article should be addressed to Joshua Wood, School of Psychology, Deakin University, Locked Bag 20000, Geelong, 3220 Australia. Email: woodjos@deakin.edu.au Phone: +61 3438197 513. This research did not receive any specific grant from funding agencies in the public, commercial, or not-for-profit sectors.
} 
1984; Uziel, 2010), personality modelling (Anglim, Lievens, Everton, Grant, \& Marty, 2018; Davies, Connelly, Ones, \& Birkland, 2015; Leising, Burger, et al., 2020), high-stakes assessment (Douglas et al., 1996; Hough, 1997; Jeong et al., 2017; Mueller-Hanson, Heggestad, \& Thornton III, 2003), and the general factor of personality (Anglim, Morse, Dunlop, Minbashian, \& Marty, 2020; Anusic, Schimmack, Pinkus, \& Lockwood, 2009; de Vries et al., 2014; Musek, 2007; Revelle \& Wilt, 2013; Van der Linden, te Nijenhuis, \& Bakker, 2010). One promising approach for contributing to these debates, and potentially reducing the effect of socially desirable responding bias, is item neutralization (Bäckström, Björklund, \& Larsson, 2009, 2014). Item neutralization involves developing personality assessments with items that have less evaluative content, as defined in the method section of this paper.

While item evaluativeness sometimes informs test development practices (e.g., Conn \& Rieke, 1994), few studies have rigorously examined the effect of reducing item evaluativeness on criterion validity and test structure. In particular, no research has yet employed the large samples required to precisely compare the criterion validity of standard and evaluatively neutralized measures. Second, no research has incorporated a comprehensive set of criteria with objective answers and other-rated criteria when assessing criterion validity. Thus, this study sought to provide a more comprehensive assessment of the impact of item neutralization on criterion validity and test structure.

\subsection{Social Desirability and Evaluativeness}

Figure 1 illustrates our conceptual model of socially desirable responding which draws inspiration from previous models by Anusic et al. (2009), Leising, Burger, et al. (2020), Leising, Vogel, et al. (2020), John and Robins (1993), Borkenau (1992), West and Kenny (2011), and McFarland and Ryan (2000). From this perspective, socially desirable responding is a directional bias that occurs when responses to personality assessments are influenced by the evaluative content of items rather than just the substantive content (Edwards, 1953; Nederhof, 1985). The degree and nature of socially desirable responding bias is theorized to be caused by the interaction of person-level and item-level effects (Anglim, Morse, De Vries, MacCann, \& Marty, 2017; Leising, Burger, et al., 2020). At the person-level, people vary in the degree to which socially desirable item content influences their responses (e.g., Bäckström \& Björklund, 2013; Bäckström et al., 2009; John \& Robins, 1994) and the nature of this influence may lead to more or less socially desirable responding bias. These tendencies are also influenced by a range of contextual factors, most notably high stakes assessments such as for employee selection, conscription, or assessing criminal liability. At the item-level, items vary in the degree to which they contain evaluative content (Anderson, 1968; Leising, Ostrovski, \& Borkenau, 2012), defined as content that is either socially desirable or socially undesirable. Various theories have elaborated on these processes (Leising, Scherbaum, Locke, \& Zimmermann, 2015) and empirical findings have highlighted how liking the target (Wessels, Zimmermann, Biesanz, \& Leising, 2020), which for self-ratings can be assessed with a self-esteem measure (Anusic et al., 2009), interacts with item evaluative content to produce socially desirable responding bias (Leising, Burger, et al., 2020; Leising, Vogel, Waller, \& Zimmermann, 2020). 
Evidence for the strong influence of item evaluativeness on responding comes from research using sets of four adjectives that are balanced for substantive (descriptive) content and social desirability. Peabody (1967) first introduced these sets of four, with an example being the synonym pair of self-controlled $(+)$ and inhibited (-) versus the synonym pair (but antonyms of the first pair) of uninhibited $(+)$ and impulsive (-), enabling descriptive and evaluative variance to be separated and contrasted. The signs in parentheses indicate whether the trait adjective was rated as having social desirability $(+)$ or social undesirability (-). Borkenau and Ostendorf (1989) found, using balanced sets of four, that participants often rate themselves and others inconsistently - that is, rate high on the traits that have positive social desirability but opposite substantive meanings. An example of inconsistency would be rating high on firm (versus lax at the other end of the scale) and high on lenient (versus severe at the other end of the scale), with firm and lenient both being positive in social desirability but opposite in descriptive content. Inconsistency was roughly twice as common as consistency (e.g., rating high on firm and severe, both being similar in descriptive content but opposite in evaluation). Pettersson, Turkheimer, Horn, and Menatti (2012) also found, from self-ratings using balanced sets of four, that an evaluative factor in exploratory SEM consisted of same-sign loadings on the factor for traits with opposite descriptive meanings but similar social desirability. Examples were sluggish and manic both loading negatively on the factor, and easy-going and driven both loading positively on the factor, despite these pairs containing nearly opposite descriptive meanings.

Socially desirable responding appears to have several effects on the structure of personality assessments. In particular, greater variation in socially desirable responding leads to increased correlations between the Big Five (Block, 1995; Costa Jr \& McCrae, 1992; Costa \& McCrae, 1992; Funder, 2001; Goldberg, 1990; McCrae \& John, 1992; Van der Linden et al., 2010). Factor analytic models of responses to personality items and scales also yield a large first factor that typically aligns social functioning, self-esteem, and well-being (Anglim et al., 2017; Anusic et al., 2009; Biderman, Nguyen, Cunningham, \& Ghorbani, 2011; Chen, Watson, Biderman, \& Ghorbani, 2016; Just, 2011; Leising et al., 2015; Reise, Moore, \& Haviland, 2010). This factor has received various labels including general factor of personality (GFP), the "Big One" (Musek, 2007), "M" (meaning or method; Chen et al., 2016) and "Halo" (Anusic et al., 2009). Regardless of the terminology, arguments about the cause of this factor mirror the arguments about agreement with items containing evaluative content. That is, some researchers emphasize that the general factor is substantive (Chen et al., 2016; Musek, 2007; van der Linden, Dunkel, \& Petrides, 2016; van der Linden et al., 2017; Van der Linden et al., 2010) while others suggest that the general factor is caused by self-enhancement biases (Anusic et al., 2009; Bäckström, 2007; Biderman et al., 2011; MacCann, Pearce, \& Jiang, 2017; Peabody \& Goldberg, 1989; Pettersson et al., 2012) and methodological artefacts (Revelle \& Wilt, 2013). In sum, researchers disagree over whether the general factor is mainly substantive personality or artefact.

There is also conflicting evidence on how socially desirable responding bias impacts criterion validity (Morgeson et al., 2007). For instance, in their Monte Carlo study, Paunonen and LeBel (2012) found that under a set of principled assumptions, 
moderate levels of socially desirable responding do not have a substantial effect on criterion validity, given the minimal rank order changes in personality scores that would be expected due to socially desirable responding. It should be noted, though, that the assumptions of their modelling caused rank ordering of scores to mostly be maintained, rather than specifying that socially desirable responders might increase their scores to similar ideal points on scales or different points that substantially disrupt rank order of scores.

\subsection{Item Neutralization}

There is also a long history of research on strategies designed to prevent, detect, and correct for socially desirable responding bias (Barrick \& Mount, 1996; Ones, Viswesvaran, \& Reiss, 1996; Schmitt \& Oswald, 2006). Prevention strategies include test instructions that emphasize the importance of honesty (Dwight \& Donovan, 2003), using subtle items (Worthington \& Schlottmann, 1986), and forced-choice response formats that ask participants to choose between equally desirable item alternatives (Bartram, 2007). Detection strategies often focus on social desirability scales (e.g., Paulhus, 1984) and over-claiming with bogus items (Dunlop et al., 2020; Phillips \& Clancy, 1972). Finally, correction strategies have often involved adjusting scores based on scores on social desirability scales (Christiansen, Goffin, Johnston, \& Rothstein, 1994; Ellingson, Sackett, \& Hough, 1999; Goffin \& Christiansen, 2003) with research suggesting that social desirability scales partially measure substantive variance and that corrections do not improve criterion validity (de Vries et al., 2014; McCrae \& Costa, 1983; Uziel, 2010). One promising but under-examined strategy for improving personality tests is to develop measures with less evaluative (i.e., more evaluatively neutral) items. Evaluative neutralization seeks to reduce the evaluative content from items while maintaining the substantive aspects of the relevant trait and thereby improve criterion validity (e.g., Leising, Burger, et al., 2020). This can be achieved through substantial rewording of items or sometimes through swapping a single trait adjective in the item for one that is less evaluative. Peabody $(1967,1984)$ and Borkenau and Ostendorf (1989) provide various examples of adjectives with similar meaning but markedly different evaluativeness (e.g., skeptical versus distrustful, selective versus choosy, and firm versus severe).

While item evaluativeness sometimes informs test development, only a few studies have examined the effect of item neutralization (e.g., Bäckström \& Björklund, 2016; Bäckström et al., 2014). In their seminal study, Bäckström et al. (2009) compared self-ratings on a standard and a neutralized measure of the Big Five. They found that the neutralized measure had smaller inter-factor correlations and a smaller first unrotated factor. However, to our knowledge, Bäckström et al. (2014) provides the only existing study to compare the criterion validity of standard and neutralized measures. They developed a neutralized measure of Big Five personality traits and compared prediction on a range of self-report criteria (e.g., self-rated popularity, creativity, gardening, and gambling) in three samples $(n=177$, $n=109$, and $n=163$ ). They found that criterion validities were similar or slightly reduced for the neutralized measure. Despite this seminal work of Bäckström and colleagues, their study had several limitations. First, because social desirability of the neutralized measure was not explicitly assessed but instead relied on item means, 
the extent of neutralization was unclear. Second, larger sample sizes are required for the statistical power needed to detect subtle differences in criterion validity between neutralized and standard questionnaires. Third, subjective self-report criteria may be confounded by similar social desirability biases that influence self-report personality assessment, and so may not provide an accurate assessment for comparing criterion validity. Indeed, Bäckström et al. (2014) explored this issue and suggested that future research should use independently measured criteria, such as other-ratings and objective measures.

\subsection{The Current Research}

The current research examined the effect of reducing evaluative item content of a Big Five personality assessment on criterion validity and test structure. The research sought to contribute to several broad debates including (a) whether neutralization yields improved criterion validity, (b) whether the general factor reflects substance or bias, and (c) whether substantive and evaluative variance can be separated. We first engaged in an extensive process of developing a less evaluative measure of Big Five personality based on the standard 50-item IPIP NEO. We then conducted a large sample study comparing test structure and criterion validity on the standard and neutralized measures. In particular, this study overcomes two key limitations of past research. First, it employed a very large sample with sufficient power to detect subtle differences in criterion validity. Second, it incorporated other-rated criteria, self-rated criteria with objective answers, and a performance measure (cognitive ability) to provide an unbiased assessment of criterion validity.

\section{Method}

Data and analysis files are available on the OSF at: https://osf.io/kfz28 . Predictions were not preregistered.

\subsection{Participants and Procedure of Main Study}

Participants in the main study $(n=3,164,81.6 \%$ female, mean age $=25.7$ years, $S D=8.6$ ) were students drawn from two undergraduate psychology units in Australia (2019 to 2020) who consented for their data to be used for research purposes. Students each received a personality report based on their responses. Participants completed the 50 standard items and the 50 neutralized items with item order within each measure randomized. The two measures were separated by 100 personality items (HEXACO) that formed part of another study. A subset of participants $(n=649)$ also completed a short cognitive ability test approximately four weeks later. For other-ratings, participants provided the name and contact details of people to be invited by email to provide ratings on the target participant via an online questionnaire. Other-ratings of participants' communication style were obtained for 1,116 target participants in 2019, each target participant having at least one other-rater (mean of 3.1 other-raters). Other-ratings of participants on the 60 item version of the HEXACO-PI-R (Ashton \& Lee, 2009) were obtained for 1,356 participants in 2020, with each target participant having at least one other-rater (also a mean of 3.1 other-raters). Finally, in order to establish retest reliability, 213 participants in the 2020 sample completed the standard and neutralized personality measures a second time, approximately four weeks after their initial completion, 
reasonably consistent with retest periods suggested by Chmielewski and Watson (2009), and Cattell (1986). For the current research, retest reliability is a valuable complement to coefficient alpha because alpha can underestimate reliability of questionnaires that lack unidimensionality (e.g., Cronbach, 1951; McNeish, 2018), and it can overestimate reliability where systematic measurement error exists, for example in the form of response biases.

The sample size was determined by the size of the underlying undergraduate units, and the main study sample size provides good precision for estimating the key parameters of interest. Specifically, the main study sought to assess differential validity between standard and neutralized conditions, where meaningful differences in correlations might be considered .05 (small) or .10 (moderate) (Bäckström et al., 2014). In general, statistical power in this design increases with (a) larger criterion validities, (b) larger differences between standard and neutralized validities, and (c) larger correlations between standard and neutralized measures. Assuming differences between criterion validities of $r=.20$ and $r=.25$, with a sample size of 3,164 and a correlation between standard and neutralized same factor scales of .80 , power was $99.5 \%$ for the main study, and assuming differences between criterion validities of $r=.20$ and $r=.23$ (with other assumptions the same) power was $78.0 \%$ for the main study. Some subsamples of criteria were smaller (e.g., other-rated communication styles $=1,116$ ) where power was $77.2 \%$ for validities of $r=.20$ and $r=.25$. We report all data exclusions and manipulations, and all measures that were analyzed are reported.

\subsection{Development of the Less Evaluative Measure}

Prior to completing the main study, we engaged in a multi-step process to develop a 50-item evaluatively neutralized Big Five measure to be used in the main study (See Table A2 in the Appendix for final items), that involved (1) item generation, (2) refinement based on expert review, (3) refinement based on social desirability and similarity ratings, (4) refinement based on a pilot study, (5) expansion of the item set and final replacement of poor items based on an additional pilot study. This measure was developed by adapting items from the 50-item IPIP NEO (Goldberg et al., 2006). We chose this measure of the Big Five because (a) it has adequate scale reliabilities, (b) it aligns well with popular representations of the Big Five, (c) it is in the public domain, and (d) it appears to have items that are reasonably evaluative (e.g., Dodaj, 2012; Kam, 2013). We sought to develop items that were similar in meaning to the standard items but which were less evaluative.

\subsubsection{Item Generation, Expert Review, and Refinement}

We used the rational approach to item development through discussion between the first and second authors, writing three to six potential items for each of the 50 items in the standard IPIP NEO questionnaire. There were 13 different strategies employed to neutralize items and these are listed in the online supplement. The list of potential neutralized items was then trimmed to two alternatives per standard item-100 in total- based on discussion between the first two authors. We then conducted a small rating task ( $n=10$, laypeople and experts) with the aim of identifying which one of the two neutralized items for each standard item should be retained. We assessed item social desirability by asking raters to indicate for each item (50 standard and 100 neutral) how favorably would others view them, if they 
agreed with the item, on a 7-point scale $(1=$ Very Unfavorable, $2=$ Moderately Unfavorable, 3 = Slightly Unfavorable, $4=$ Neutral - neither Favorable nor Unfavorable, 5 = Slightly Favorable, $6=$ Moderately Favorable, and $7=$ Very Favorable). Item evaluativeness was the distance from perfect neutrality and was calculated as the absolute deviation of item social desirability from the scale midpoint (i.e., 4 on the 1 to 7 scale), that is, absolute of mean social desirability (17) minus 4. Participants then rated how similar in meaning the standard item was to each of the neutralized alternatives (i.e., item similarity), responding to the question, "How similar in meaning are the following two statements", on a 5-point scale $(1=$ Not similar at all, $2=$ Only slightly similar, $3=$ Moderately similar; $4=$ Very similar, and $5=$ Extremely similar). Item social desirability and similarity scores were the means of all ratings. Table S1 of the online supplement shows mean social desirability and mean similarity in meaning for each item. For each standard item, the better neutralized item of the pair was chosen based on the score on a measure of item goodness, defined as similarity $+(4 \mathrm{x} \mid$ evaluativeness $-4 \mid)$, however a minimum threshold of similarity $\geq 2$ was required.

\subsubsection{Pilot Study}

We then conducted a pilot study, in 2018, similar to the main study reported here, albeit with a smaller sample. Participants $(n=687,81.5 \%$ female, mean age $=$ 25.2 years, $S D=7.5$ ) were drawn from an undergraduate psychology unit in Australia. Based on all data cleaning and screening, 17 participants were excluded from further analysis, based on missing data $(\mathrm{n}=15)$ or random, inattentive responding $(\mathrm{n}=2)$. They completed the 50 standard and 50 pilot neutralized personality items with all items interspersed and in randomized order. They then completed a set of self-report criteria. Finally, they rated the item social desirability of a random subset of 5 standard and 5 neutralized personality items on a 7-point scale $(1=$ Very Undesirable, $2=$ Moderately Undesirable, $3=$ Slightly Undesirable, 4 = Neutral - neither desirable nor undesirable, $5=$ Slightly Desirable, $6=$ Moderately Desirable, and $7=$ Very Desirable). Psychometric results from this pilot study are reported in the online supplement. Based on analyses of the pilot data, the poorest quality neutralized items out of each Big Five scale were flagged for potential replacement where poor quality was determined by low corrected itemtotal correlation or lowest correlation between the standard and neutralized itempair. Table S3 of the supplement contains interscale correlations for this pilot and scale alphas, based on scales with the two poorest items removed. Table S4 contains criterion validities for 23 criteria in the pilot.

\subsubsection{Additional Item Development}

We then sought to develop new items to replace the poorer items. In an initial stage of questionnaire refinement, in 2019, before the main study, we engaged in a two-step process to test new items. We first piloted 84 new evaluatively neutralized items (counterparts to 27 standard items, with some old neutralized items having up to four alternatives created) with a sample of 25 participants from Mechanical Turk, who rated item social desirability and similarity in meaning to the standard item counterpart. We then asked 145 participants from Mechanical Turk (59\% male) to self-report and rate social desirability of 74 neutralized items (counterparts to 27 standard items) from the pilot that were deemed satisfactory (adequate corrected 
item-total correlations and evaluativeness, superior to the neutral item results from the pilot sample with $n=687$ ) plus 50 standard items. This testing resulted in 24 new neutralized items that had adequate corrected item-total correlations, standardneutralized item-pair self-rating correlations, and evaluativeness lower than the standard counterpart. These replaced 24 neutralized items from the first pilot study $(n=687)$ that had low corrected item-total correlations (reducing scale alphas), low standard-neutralized item-pair self-rating correlations, or high evaluativeness. The final items are shown in Table A2 of the Appendix and their psychometric properties are included in Table S5 of the online supplement. Table S6 of the supplement shows item loadings from principal component analysis, for both measures.

\subsection{Measures}

\subsubsection{Personality}

The Big Five personality traits were measured using standard and neutralized measures where each standard item had an analogous neutralized item. The standard measure was the 50-item IPIP NEO (Goldberg et al., 2006) and the neutralized measure was the final set of 50 items described above (See Table A2 in the Appendix for final items). Items on both measures were rated on a 5-point scale, where $1=$ Strongly Disagree, 2 = Disagree, 3 = Neutral (neither agree nor disagree), $4=$ Agree, and 5 = Strongly Agree. Scale scores were the mean after relevant item reversal.

\subsubsection{Self-Report Criteria}

The study included 16 self-report criteria (see Table A1 in the Appendix for question details). These were chosen from the 23 criteria in the pilot that had the highest criterion validities (see Table S4 of the supplement). Criteria were chosen where: (1) they had an objective answer, (2) participants were likely to know the answer, (3) there would be minimal incentive to answer dishonestly, and (4) there was evidence that Big Five personality predicts the criteria. Of the 16 criteria, the following were binary (coded $0=$ no, $1=$ yes): donated blood in the past 24 months, played a musical instrument in the last month, ever attended heavy metal concert, ever attended ballet, ever attended a football match, ever publicly protested, and is female. The following variables were numeric: Average university grade (0 to 100), number of times exercising per week, typical hour of getting out of bed on the weekend ( 0 to 24$)$, and age (years). The following variables were ordinal scales: frequency of brushing teeth (from "never" to "more than three times per day"), alcohol consumption (from "non-drinker" to "heavy drinker"), and frequency of attendance of place of religious worship (from "do not ever go to a place of worship" to "go to a place of worship very frequently"). The following criteria were recoded to binary: number of cigarettes per day and number of tattoos was coded $1=$ yes if more than "None" and 0 is "None". Social desirability of criteria were also measured (see Table S7 of supplement for details).

\subsubsection{Other-Report Criteria}

The 2019 cohort provided other-ratings for four facets of the expressiveness scale from the Communication Styles Inventory (de Vries, Bakker-Pieper, Konings, \& Schouten, 2013): talkativeness, conversational dominance, humor, and informality. The 2020 cohort provided other ratings on the six scales of the 60 -item 
HEXACO PI R (Ashton \& Lee, 2009): honesty-humility, emotionality, extraversion, agreeableness, conscientiousness, and openness. All items had response options of $1=$ Strongly Disagree, $2=$ Disagree, $3=$ Neutral (neither agree nor disagree), $4=$ Agree, and 5 = Strongly Agree. Other-ratings for participants with more than one rater were averaged.

\subsubsection{Cognitive Ability}

Cognitive ability was measured using the 16-item version of the International Cognitive Ability Resource (ICAR; Condon \& Revelle, 2014). This measure contains four subtests, each with four items, labelled (1) verbal reasoning, (2) letter and number series, (3) matrix reasoning, and (4) three-dimensional rotation. Items included between 6 and 8 response options. Responses were required for all items and completion had no time limit. An overall measure of cognitive ability was calculated as the percentage of items correct. Cronbach's alpha was .78.

\subsubsection{Item Social Desirability and Evaluativeness}

Item social desirability was obtained for all 100 items, based on ratings from both the pilot study $(n=687)$ and the main study $(n=3,164)$ which contained replaced neutralized items. In the main study, a subset of participants rated the social desirability of random subsets of the 24 new neutralized items and their standard counterparts. To allow accurate comparison, standard and neutralized item counterparts were always rated together by the same sample. Therefore, we used social desirability ratings, by the subset of the main sample, of the 24 new pairs of items (containing 24 new neutralized items). We used social desirability ratings, by the pilot sample $(n=687)$, of the 26 other pairs of items (not affected by updating the 24 neutralized items). Across both the pilot and the main study, each item had social desirability rated by between 64 and 75 participants, on a 7-point scale $(1=$ Very Undesirable, 2 = Moderately Undesirable, $3=$ Slightly Undesirable, $4=$ Neutral - neither desirable nor undesirable, $5=$ Slightly Desirable, $6=$ Moderately Desirable, and $7=$ Very Desirable). Item social desirability was calculated as the mean of social desirability ratings. Item evaluativeness was defined as how desirable or undesirable the item was (John \& Robins, 1993), regardless of the direction, and was calculated as the absolute distance of item social desirability from the neutral midpoint (i.e., 4 on the 1 to 7 social desirability scale). Thus, a socially $u n d e s i r a b l e$ item (e.g., social desirability of 2) and socially desirable item (e.g., social desirability of 6) would both have the same evaluativeness rating of 2 (i.e., absolute difference from 4). The reliability of mean item social desirability ratings was .99 . This was estimated using a random effects linear model (item and rater were random) and calculating the item variance over the sum of item variance and error variance associated with estimating the item mean.

\subsection{Data Analytic Approach}

Criterion validities of the standard and neutralized measures were compared by examining bivariate correlations and regression models predicting each criterion from the Big Five of each measure. Bivariate correlations with criteria were compared using Steiger's z (Steiger, 1980). A threshold of $p<.001$ was used for the criterion validities and Steiger's $z$, to reduce the chance of type I errors, given the large number of significance tests. Adjusted multiple R from regression models for 
standard and neutralized measures were statistically compared using a custom bootstrap function written in R that involved sampling with replacement for 2000 iterations (see OSF repository for details). The size of a general factor in each questionnaire version was estimated using the intercorrelations between the five scales and the percentage of variance explained by the first unrotated factor in principal component analysis of the items.

\section{Results}

\subsection{Item-Level Analysis}

In order to understand the effectiveness of the item neutralization process, we first examined item-level characteristics. In general, item-level analyses showed that the neutralized measure had much less evaluative content than the standard measure (see online supplement for detailed item-level analysis). Specifically, mean item evaluativeness was much lower for the neutralized measure $(M=1.02, S D=$ $0.69)$ than for the standard measure $(M=1.66, S D=0.70)$, paired-samples $t(49)=$ $-9.85, p<.001, d=-0.92,95 \%$ CI $[-1.31,-0.53]$. This held true for all Big Five scales, where mean item evaluativeness was as follows: neuroticism (standard $=$ 1.61 ; neutralized $=0.94)$, extraversion (standard $=1.41$; neutralized $=0.75)$, openness $($ standard $=1.00$; neutralized $=0.61)$, agreeableness $($ standard $=2.23$; neutralized $=1.33$ ), and conscientiousness $($ standard $=2.06$; neutralized $=1.47)$. Of the 50 item pairs, 47 had lower evaluativeness for the neutralized version. Similarly, mean scale social desirability ratings (i.e., average item social desirability for the scale after reversing reversed items) was closer to neutrality (i.e., 4 on the 1 to 7 scale) in the neutralized measure for all Big Five scales: neuroticism (standard = 2.39; neutralized $=3.06)$, extraversion $($ standard $=5.29$; neutralized $=4.66)$, openness $($ standard $=5.00$; neutralized $=4.40)$, agreeableness $($ standard $=6.23$; neutralized $=5.33$ ), and conscientiousness (standard $=6.06$; neutralized $=$ 5.47). Finally, the overall social desirability difference from the neutral midpoint of the measures, calculated as the mean of social desirability (1-7), minus 4, after reversing reversed items and reversing neuroticism, was 0.96 for the neutralized measure and 1.64 for the standard measure. This indicates that, overall, the standard measure had mean social desirability $71 \%$ further from the neutral midpoint than the neutralized measure.

We also examined differences in item means between the measures given that they often align, albeit imperfectly, with item social desirability. After reversing reverse-keyed items and reversing neuroticism for this specific analysis, item means were significantly lower for the neutralized measure $(M=2.93, S D=0.44)$ than the standard measure $(M=3.48, S D=0.48)$, paired-sample $t(49)=11.06, p<.001, d=$ $1.56,95 \%$ CI $[1.28,1.85]$. Item means were also closer to the scale mid-point for the neutralized measure. Specifically, the absolute distance of item means from the scale midpoint (i.e., distance from an item mean of 3) was lower for neutralized items $(M=0.37, S D=0.24)$ than for standard items $(M=0.57, S D=0.36)$. Interestingly, item means were correlated with item social desirability in the standard but not the neutralized measure: $r(98)=.53, p<.001,95 \% \mathrm{CI}[.37, .66]$ for all 100 items, $r(48)=.74, p<.001,95 \%$ CI $[.58, .84]$ for the standard items, and $r(48)=.02, p=.88,95 \%$ CI $[-.26, .30]$ for the neutralized items. The substantial 
reduction in evaluative variance and the close proximity of item means to the scale mid-point in the neutralized measure may explain this difference.

\subsection{Descriptive Statistics and Psychometrics}

Table 1 shows descriptive statistics and correlations for the standard and neutralized measures. Estimates of alpha using Cronbach's alpha (mean alpha: standard $=.81$, neutralized $=.79$ ) and retest correlations (mean retest correlation: standard $=.89$, neutralized $=.87$ ) were generally high and similar across the two forms of measures. Correlations between corresponding standard and neutralized Big Five scales were high enough to indicate they measured similar constructs, but not so high as to indicate that no meaningful changes were made to items: .81 (neuroticism), .83 (extraversion), .78 (openness), .71 (agreeableness), and .77 (conscientiousness). When corrected for attenuation using test-retest correlations, the corrected correlations between corresponding standard and neutral scales were .93 (neuroticism), .92 (extraversion), .88 (openness), .84 (agreeableness), and .87 (conscientiousness).

Consistent with a reduction in evaluative variance in the neutralized measure, several statistics highlighted that the general factor was smaller for the neutral measure than for the standard measure. First, the average of the 10 Big Five intercorrelations after reversing neuroticism was much lower in the neutralized measure (mean $r=.09$ ) than in the standard measure (mean $r=.19$ ). Second, the percentage of variance explained by the first unrotated component of items was also lower for the neutralized measure (12.4\%) than for the standard measure $(16.7 \%)$.

\subsection{Criterion Validity}

Correlations between the criteria and Big Five scales for the standard and neutralized measures are reported in Table 2. All criteria except one had a multiple correlation with the Big Five greater than $r=.10$ and the general pattern of correlations was broadly consistent with past research. For instance, conscientiousness was a good predictor of academic grades, getting up early, exercising, and brushing teeth regularly, and openness was a good predictor of attending protests, the ballet, and heavy metal concerts. Other-rated communication styles correlated highly with self-reported extraversion. Furthermore, the correlations with other-rated HEXACO personality were large for scales closely aligned with the Big Five (i.e., extraversion, conscientiousness, and openness) and more modest for the reconfigured traits of HEXACO honesty-humility, agreeableness, and emotionality.

In general, the pattern of bivariate criterion validities for the standard and neutralized measures were similar, albeit the neutralized measure had correlations that were slightly lower. Bivariate correlations $r \geq .10$ are shown in bold, for clarity. Using Steiger's z (Steiger, 1980) to compare correlations, of the 76 standardneutralized pairs of criterion validities where the standard or neutralized scale, or both, was significant at $p<.001,52$ were not significantly different, 21 were larger for the standard measure and 3 were larger for the neutralized measure (with all significant differences at $p<.001$ denoted with a single asterisk). Also, the average absolute correlations with criteria were slightly larger for the standard measure than for the neutralized measure (neuroticism: .11 versus .10; extraversion: .15 versus .14; openness: .11 versus .09; agreeableness: .08 versus .07: conscientiousness: .10 
versus .08). In general, the small differences in criterion validities between the standard and neutralized measures were larger for correlations with other-ratings (i.e., other rated personality and communication styles) than for the more objective cognitive ability measure and self-report criteria, which may reflect the fact that the other-rated measures were written in a style that was more similar to the standard Big Five or may reflect the fact that the other-rated validities were generally larger for both measures. Social desirability ratings of self-rated criteria were also measured and further analysis of the potential impact on comparative criterion is provided in the online supplement (see Table S7). However, there was no clear relationship between criterion evaluativeness and criterion validity.

We also compared adjusted multiple correlations of regression models predicting each criteria from the Big Five using either the standard or the neutralized scales (see Table 2). These results largely mirrored the bivariate results, whereby validities were similar but the multiple correlation was sometimes a little smaller for the neutralized measure. Of the 27 criteria, six had significantly larger adjusted multiple $\mathrm{R}$ values for the standard measure compared to the neutralized measure at $p<.001$ (i.e., university grade, get-up lateness, age, other-rated informality, and other-rated HEXACO extraversion and conscientiousness). Overall, the average adjusted multiple correlation was .31 for the standard measure and .28 for the neutralized measure (i.e., $9 \%$ less). If we were to assume that criterion validity declined linearly with reductions in overall evaluativeness, we could extrapolate that a measure with zero evaluativeness would have a mean multiple correlation of .24, although it is uncertain whether an assumption of linearity would be justifiable.

\section{Discussion}

The current research examined the effect of reducing item evaluativeness on the structure and criterion validity of personality assessments. Several key findings emerged. First, we demonstrated that it is possible to create a measure of the Big Five with substantially less evaluative items that still correlates highly with the original scale and maintains sound scale reliability. Second, neutralization reduced inter-scale correlations and variance explained by a general factor of personality. Third, neutralization led to generally similar but in some cases slightly weaker criterion validity. These findings have implications for conceptualizations of personality, social desirability, and test development.

\subsection{Personality Structure}

Consistent with Bäckström et al. (2009) and Bäckström and Björklund (2016), evaluative neutralization of items reduced indicators of a general factor. The first principal component of items and the correlations between the Big Five were both smaller for the neutralized measure. This is also consistent with the conclusions reached by Bäckström and Björklund (2020; published while the current research was under review), where a neutralized measure virtually eliminated a CFA evaluative factor, general factor, and higher-order factors, as well as increased discriminant validity with other psychological measures. This suggests that the size of the general factor of personality is influenced by the amount of evaluative content in the Big Five scales. Nonetheless, this alone does not prove whether this evaluative content reflects substance or bias. 
Importantly, scale reliabilities were very similar across the two measures, albeit slightly lower for the neutralized measure, both for Cronbach's alphas and retest reliabilities. This slight difference is unsurprising given that evaluative bias was expected to artificially inflate reliability estimates (Leising et al., 2015). Likewise, any socially desirable responding bias may persist over time to inflate test-retest correlations in the standard measure. Furthermore, there is often a tradeoff between validity and reliability. In particular, some strategies that increase reliability (e.g., highly homogenous items, lack of balancing on normal and reversed items, etc.) can reduce criterion validity (Clifton, 2020), that is, the attenuation paradox (Loevinger, 1954).

\subsection{Criterion Validity}

Overall, criterion validity was mostly similar across the standard and neutralized measures of the Big Five but in some instances it was slightly lower for the neutralized measure. While this finding is broadly consistent with past research (Bäckström et al., 2014) the use of other ratings, objective criteria, a very large sample, and an independent process for developing a neutralized measure substantially strengthens this conclusion.

Overall, the current research supports the claim that the social desirability of personality traits is partially intrinsic and partially the result of item writing practices. For instance, the current research highlights that it is possible to substantially reduce the social desirability, and indeed the evaluativeness, of Big Five scales while retaining high correlations with standard measures and achieving similar, albeit slightly reduced, predictive validity compared to a standard measure. Nonetheless, altering the social desirability of items that operationalize personality traits may also subtly alter the meaning of the trait, and these subtle changes in meaning may impact the nature of predictive validity. For instance, it may be the case that removing the socially desirable aspects of a trait slightly reduces the predictive validity of socially desirable criteria. Thus, neutralized measures may be appropriate where a researcher seeks to operationalize the Big Five in less evaluative terms.

One interpretation of the findings of similar or slightly reduced predictive validity in neutralized measures is that any improvements resulting from less socially desirable responding bias, are offset by reductions in useful descriptive content. This may particularly be the case in low stakes settings where participants are motivated to answer honestly, and any negative effects of social desirability bias are more related to self-deception or mild concerns about anonymity. In particular, the simulation work of Paunonen and LeBel (2012) suggests that moderate levels of socially desirable responding bias results in relatively small declines in predictive validity. Thus, it may be that in low stakes settings the potential predictive validity gains are only slight.

Of the Big Five, conscientiousness had the most criteria involving a reduction in criterion validity for the neutralized measure (e.g., university grades, getting up late, attending ballet, age, plus HEXACO honesty-humility, extraversion and conscientiousness) but the neutralized conscientiousness scale also had higher criterion validity for alcohol consumption, publicly protesting, and HEXACO openness. In general, it was challenging to neutralize conscientiousness items while 
retaining the meaning of the original construct. It may be that the elements making conscientiousness a good predictor of achievement and health behaviors are intrinsically socially desirable. For example, being hard working and disciplined may lead to behaviors such as studying hard, frequently exercising, and brushing one's teeth regularly, which in turn lead to socially desirable outcomes such as high grades, successful careers, physical fitness, and good dental hygiene. Personality questionnaires measure the substantive content of attributes that may be intrinsically socially desirable. As McCrae and Mõttus (2019) point out, trying to separate substance and bias using measures of evaluative bias and statistically correcting for it has not been especially effective, because measures of evaluative bias themselves contain substantive trait variance. Our results suggest the substantive and evaluative parts of items are often related, making it difficult to remove one without the other. This may be especially the case for some individual difference terms, for example, stupid or murderer, which do not have clear evaluatively positive synonyms. Future research may investigate a much broader range of trait adjectives to more generally ascertain how separable their evaluative and descriptive elements are. After all, the current research adapted a standard questionnaire with only 50 items, while there were nearly 18,000 trait terms to describe people in 1936 (Allport \& Odbert, 1936), and there are likely to be many more now.

An alternative interpretation of the results is that substantive psychological traits such as self-esteem correlate with certain criteria and also predict socially desirable responding (Leising, Burger, et al., 2020). From this perspective, substantive psychological traits increase criterion validity at the same time as leading to greater bias in responding. In general, with the exception of some of the other-rated measures, we sought to measure relatively objective criteria and avoid focusing on more subjective outcomes such as subjective well-being. If anything, it seems likely that one of the key effects of neutralization is to remove content like self-efficacy, self-esteem, and well-being that are often captured by measures of the general factor of personality.

In general, the research reinforced the idea that removing evaluative item content is an effective way of reducing the pattern of Big Five intercorrelations consistent with the general factor of personality (see Musek, 2007; van der Linden et al., 2016). Similarly, moving Big Five scale means closer to scale mid-points may also have further reduced intercorrelations. However, ultimately the standard measure, that had larger factor correlations, did not show declines in criterion validity. Thus, in totality, the results suggest that developing personality scales that are perfectly orthogonal may involve trade-offs with validity.

We note also that evaluative content was reduced but not removed entirely. Future research could refine a neutralized measure through further iterations of item testing, aiming to come as close to perfectly neutral items as possible, given a particular culture and sample. However, given that it may not be possible to completely remove evaluative content while maintaining criterion validity, a complementary approach to scale development may be to evaluatively balance items, following similar principals to those of Borkenau and Ostendorf (1989) and Pettersson et al. (2012), who experimented with balanced sets of four. Evaluative balancing involves having an even mix of slightly desirable and slightly undesirable 
items in a scale - after item reversal. For example, for the scale of extraversion in the current study, two items that measure the introverted end of the extraversion scale were "I hold back my opinions" (rated as slightly socially undesirable) and "I prefer not to do things that draw attention to myself" (rated as slightly socially desirable). We know from previous research (Borkenau \& Ostendorf, 1989) that evaluative balancing like this may lead to respondents answering somewhat inconsistently regarding descriptive content, if they have an inclination to answer consistently on social desirability valence, which may lower scale consistencies. However, reduced scale consistencies would suggest that scale consistencies had previously been artificially boosted by item evaluative content.

Neutralized measures may also be particularly valuable in contexts where limiting the impact of socially desirable responding bias is of theoretical or applied importance. For instance, it provides a means for assessing theories of personality factor structure (Bäckström \& Björklund, 2020) and also whether correlations with criteria are moderated, possibly artificially, by evaluative content (Bäckström \& Björklund, 2020). It also has important applied implications for high-stakes testing contexts, such as employee selection. Job applicants can and do distort their responses to personality assessments (Anglim et al., 2018; Anglim et al., 2017; Birkeland, Manson, Kisamore, Brannick, \& Smith, 2006; Rothstein \& Goffin, 2006). As such, practitioners are keen to identify strategies that reduce the impact of socially desirable responding bias, such as subtle items (Worthington \& Schlottmann, 1986), forced-choice formats (Bartram, 2007), and warnings (Mcfarland, 2003). In such settings, any negative effects of neutralization might be offset by reduced faking. This represents an important area of future research.

\subsection{Limitations}

Several limitations should be noted. First, it is worth considering whether socially desirable responding bias influenced answers for some of the self-report criteria. If this led to socially desirable responding bias or self-enhancing responding for both the predictor and the criterion, it would create common method bias, artificially increasing the criterion validity for the standard measure more than for the neutralized measure. This may also have occurred in past research when predicting self-reported variables related to psychological adjustment, such as selfcontrol, humility, and social knowledge (Chen et al., 2016), and other variables such as self-rated popularity, attractiveness, intelligence, and honesty (Bäckström et al., 2014). In the current research, criteria were carefully chosen to permit a clear and objective answer and included such criteria as age. Furthermore, the other-report criteria removed this confound. Criteria social desirabilities were also measured and the most evaluative criteria, in descending order, were exercise frequency, dental brushing frequency, university grade, smoker, and alcohol consumption (see Table S7 of the supplement). The criteria showing the greatest differences in criterion validity between standard and neutralized versions were university grade, get-up lateness, and age. There is no clear difference between standard and neutralized measures in the relationship between evaluativeness of criteria and level of criterion validity (see supplement for analyses). Nonetheless, future research should continue to examine other-ratings and other alternatives to self-report criteria. 
Second, any modifications to an already optimized personality questionnaire may inadvertently lead to production of poorer psychometric properties and consequently reduced criterion validity, despite the rigorous, multi-step questionnaire development process. For example, some of the neutralized items were longer than their original counterparts. We used thirteen different techniques to reduce item evaluativeness (see supplement for details) and future research may examine which are the most effective methods for substantially reducing evaluative content, while still maintaining criterion validity and other test psychometric properties. However, the reasonably high scale retest reliabilities and alphas, and correlations between standard and neutralized scale pairs, suggest the neutralized questionnaire was psychometrically sound. That said, future research could examine the relative impact on test structure and validity of different methods of item neutralization.

Third, when initially ascertaining the similarity of standard and potential neutralized items, we asked participants in the very first pilot $(n=10)$, "How similar in meaning are the following two statements". While this wording suggests participants should focus on the similarity of the descriptive content of items, rather than similarity in evaluativeness, these could possibly be even more clearly separated by explicitly asking participants to ignore the evaluative aspect of the items, for example, "To what extent do these items describe the same actual traits or behaviors, irrespective of whether the different descriptions cast a more positive or more negative light on a target". This type of wording could potentially be used in future research.

Finally, the fact that our main sample was mostly young adults and over $80 \%$ female may influence the generalizability of the social desirability ratings. That said, the correlation between male and female social desirability ratings was very high: $r(98)=.96, p<.001,95 \%$ CI $[.94, .97]$. This is broadly consistent with our expectations that while social desirability ratings do vary, there is a large common core within a given social-historical context.

\subsection{Conclusion}

In conclusion, our research showed that the evaluative content of a standard measure of personality can be reduced and that this reduces the size of scale intercorrelations and loadings on the first factor in principal component analysis. This provides evidence for the theoretical argument that evaluative content partly contributes to a general factor. Criterion validities were slightly smaller for measures with reduced evaluative content, providing evidence that item evaluative content also has a substantive element. Even if evaluative content leads to increased directional bias, through encouragement of self-enhancement, removal of this content results in a slight net reduction in prediction. It may be that this loss of substantive content is not fully offset by the removal of measurement distortion. 


\section{References}

Allport, G. W., \& Odbert, H. S. (1936). Trait-names: A psycho-lexical study. Psychological Monographs, 47(1), i.

Anderson, N. H. (1968). Likableness ratings of 555 personality-trait words. Journal of Personality and Social Psychology, 9(3), 272-279. doi:https://doi.org/10.1037/h0025907

Anglim, J., Lievens, F., Everton, L., Grant, S. L., \& Marty, A. (2018). HEXACO personality predicts counterproductive work behavior and organizational citizenship behavior in low-stakes and job applicant contexts. Journal of Research in Personality, 77, 11-20. doi:https://doi.org/10.1016/j.jrp.2018.09.003

Anglim, J., Morse, G., De Vries, R. E., MacCann, C., \& Marty, A. (2017). Comparing job applicants to non-applicants using an item-level bifactor model on the HEXACO personality inventory. European Journal of Personality, 31(6), 669-684. doi:https://doi.org/10.1002/per.2120

Anglim, J., Morse, G., Dunlop, P. D., Minbashian, A., \& Marty, A. (2020). Predicting trait emotional intelligence from HEXACO personality: Domains, facets, and the general factor of personality. Journal of Personality, 88, 324-338. doi:https://doi.org/10.1111/jopy.12493

Anusic, I., Schimmack, U., Pinkus, R. T., \& Lockwood, P. (2009). The nature and structure of correlations among Big Five ratings: The halo-alpha-beta model. Journal of Personality and Social Psychology, 97(6), 1142-1156. doi:https://doi.org/10.1037/a0017159

Ashton, M. C., \& Lee, K. (2009). The HEXACO-60: A short measure of the major dimensions of personality. Journal of Personality Assessment, 91(4), 340-345. doi:https://doi.org/10.1080/00223890902935878

Bäckström, M. (2007). Higher-order factors in a five-factor personality inventory and its relation to social desirability. European Journal of Psychological Assessment, 23(2), 63-70. doi:https://doi.org/10.1027/1015-5759.23.2.63

Bäckström, M., \& Björklund, F. (2013). Social desirability in personality inventories: Symptoms, diagnosis and prescribed cure. Scandinavian Journal of Psychology, 54(2), 152-159. doi:https://doi.org/10.1111/sjop.12015

Bäckström, M., \& Björklund, F. (2016). Is the general factor of personality based on evaluative responding? Experimental manipulation of item-popularity in personality inventories. Personality and Individual Differences, 96, 31-35. doi:https://doi.org/10.1016/j.paid.2016.02.058

Bäckström, M., \& Björklund, F. (2020). The properties and utility of less evaluative personality scales: Reduction of social desirability; increase of construct and discriminant validity. Frontiers in Psychology, 11.

Bäckström, M., Björklund, F., \& Larsson, M. R. (2009). Five-factor inventories have a major general factor related to social desirability which can be reduced by framing items neutrally. Journal of Research in Personality, 43(3), 335-344. doi:https://doi.org/10.1016/j.jrp.2008.12.013

Bäckström, M., Björklund, F., \& Larsson, M. R. (2014). Criterion validity is maintained when items are evaluatively neutralized: Evidence from a full-scale Five-Factor Model inventory. European Journal of Personality, 28(6), 620-633. doi:https://doi.org/10.1002/per.1960

Barrick, M. R., \& Mount, M. K. (1996). Effects of impression management and self-deception on the predictive validity of personality constructs. Journal of Applied Psychology, 81(3), 261-272. doi:https://doi.org/10.1037/0021-9010.81.3.261

Bartram, D. (2007). Increasing validity with forced-choice criterion measurement formats. International Journal of Selection and Assessment, 15(3), 263-272. doi:https://doi.org/10.1111/j.1468-2389.2007.00386.x

Biderman, M. D., Nguyen, N. T., Cunningham, C. J., \& Ghorbani, N. (2011). The ubiquity of common method variance: The case of the Big Five. Journal of Research in Personality, 45(5), 417-429. doi:https://doi.org/10.1016/j.jrp.2011.05.001

Birkeland, S. A., Manson, T. M., Kisamore, J. L., Brannick, M. T., \& Smith, M. A. (2006). A meta-analytic investigation of job applicant faking on personality measures. International Journal of Selection and Assessment, 14(4), 317-335. doi:https://doi.org/10.1111/j.1468-2389.2006.00354.x

Block, J. (1995). A contrarian view of the five-factor approach to personality description. Psychological Bulletin, 117(2), $187-215$. doi:https://doi.org/10.1037/0033-2909.117.2.187

Borkenau, P. (1992). Implicit Personality Theory and the Five - Factor Model. Journal of Personality, 60(2), 295-327.

Borkenau, P., \& Ostendorf, F. (1989). Descriptive consistency and social desirability in self - and peer reports. European Journal of Personality, 3(1), 31-45.

Cattell, R. (1986). The psychometric properties of tests: Consistency, validity, and efficiency. Functional psychological testing: Principles and instruments, 54-78.

Chen, Z., Watson, P., Biderman, M., \& Ghorbani, N. (2016). Investigating the properties of the general factor (M) in Bifactor models applied to Big Five or HEXACO data in terms of method or meaning. Imagination, Cognition and Personality, 35(3), 216-243. doi:https://doi.org/10.1177/0276236615590587

Chmielewski, M., \& Watson, D. (2009). What is being assessed and why it matters: the impact of transient error on trait research. Journal of Personality and Social Psychology, 97(1), 186-202. doi:https://doi.org/10.1037/a0015618

Christiansen, N. D., Goffin, R. D., Johnston, N. G., \& Rothstein, M. G. (1994). Correcting the 16PF for faking: effects on criterionrelated validity and individual hiring decisions. Personnel Psychology, 47(4), 847-860. doi:https://doi.org/10.1111/j.1744-6570.1994.tb01581.x

Clifton, J. D. W. (2020). Managing validity versus reliability trade-offs in scale-building decisions. Psychological Methods, 25(3), 259-270. doi:https://doi.org/10.1037/met0000236

Condon, D. M., \& Revelle, W. (2014). The International Cognitive Ability Resource: Development and initial validation of a public-domain measure. Intelligence, 43, 52-64. doi:https://doi.org/10.1016/j.intell.2014.01.004

Conn, S. R., \& Rieke, M. L. (1994). 16PF fifth edition technical manual: Institute for Personality \& Ability Testing, Incorporated. 
Costa Jr, P. T., \& McCrae, R. R. (1992). Four ways five factors are basic. Journal of Personality and Individual Differences, 13(6), 653-665. doi:https://doi.org/10.1016/0191-8869(92)90236-I

Costa, P. T., \& McCrae, R. R. (1992). Normal personality assessment in clinical practice: The NEO Personality Inventory. Psychological Assessment, 4(1), 5-13. doi:https://doi.org/10.1037/1040-3590.4.1.5

Cronbach, L. J. (1951). Coefficient alpha and the internal structure of tests. Psychometrika, 16(3), $297-334$. doi:https://doi.org/10.1007/bf02310555

Davies, S. E., Connelly, B. S., Ones, D. S., \& Birkland, A. S. (2015). The General Factor of Personality: The "Big One," a selfevaluative trait, or a methodological gnat that won't go away? Personality and Individual Differences, 81, $13-22$. doi:https://doi.org/10.1016/j.paid.2015.01.006

de Vries, R. E., Bakker-Pieper, A., Konings, F. E., \& Schouten, B. (2013). The communication styles inventory (CSI) a sixdimensional behavioral model of communication styles and its relation with personality. Communication Research, 40(4), 506-532. doi:https://doi.org/10.1177/0093650211413571

de Vries, R. E., Zettler, I., \& Hilbig, B. E. (2014). Rethinking trait conceptions of social desirability scales: Impression management as an expression of honesty-humility. Assessment, 21(3), 286-299. doi:https://doi.org/10.1177/1073191113504619

Dodaj, A. (2012). Social desirability and self-reports: Testing a content and response-style model of socially desirable responding. Europe's Journal of Psychology, 8(4), 651-666. doi:https://doi.org/10.5964/ejop.v8i4.462

Douglas, E. F., McDaniel, M. A., \& Snell, A. F. (1996). The validity of non-cognitive measures decays when applicants fake. Paper presented at the Academy of Management Proceedings.

Dunlop, P. D., Bourdage, J. S., de Vries, R. E., McNeill, I. M., Jorritsma, K., Orchard, M., . . Choe, W.-K. (2020). Liar! Liar!(when stakes are higher): Understanding how the overclaiming technique can be used to measure faking in personnel selection. Journal of Applied Psychology, 105(8), 784-799. doi:https://doi.org/10.1037/apl0000463

Dwight, S. A., \& Donovan, J. J. (2003). Do warnings not to fake reduce faking? Human Performance, 16(1), 1-23. doi:https://doi.org/10.1207/s15327043hup1601 1

Edwards, A. L. (1953). The relationship between the judged desirability of a trait and the probability that the trait will be endorsed. Journal of Applied Psychology, 37(2), 90-93. doi:https://doi.org/10.1037/h0058073

Ellingson, J. E., Sackett, P. R., \& Hough, L. M. (1999). Social desirability corrections in personality measurement: Issues of applicant comparison and construct validity. Journal of Applied Psychology, 84(2), 155-166. doi:https://doi.org/10.1037/0021-9010.84.2.155

Funder, D. C. (2001). Personality. Annual Review of Psychology, 52, 197-221. doi:https://doi.org/10.1146/annurev.psych.52.1.197.

Goffin, R. D., \& Christiansen, N. D. (2003). Correcting personality tests for faking: A review of popular personality tests and an initial survey of researchers. International Journal of Selection and Assessment, 11(4), 340-344. doi:https://doi.org/10.1111/j.0965-075X.2003.00256.x

Goldberg, L. R. (1990). An alternative "description of personality": The Big-Five factor structure. Journal of Personality and Social Psychology, 59(6), 1216-1229. doi:https://doi.org/10.1037/0022-3514.59.6.1216

Goldberg, L. R., Johnson, J. A., Eber, H. W., Hogan, R., Ashton, M. C., Cloninger, C. R., \& Gough, H. G. (2006). The international personality item pool and the future of public-domain personality measures. Journal of Research in Personality, 40(1), 84-96. doi:https://doi.org/10.1016/j.jrp.2005.08.007

Hough, L. M. (1997). Personality at work: Issue and evidence. In M. D. Hakel (Ed.), Beyond multiple choice: Evaluating alternatives to traditional testing for selection (pp. 131-166): Lawrence Erlbaum Associates.

Jeong, Y. R., Christiansen, N. D., Robie, C., Kung, M. C., \& Kinney, T. B. (2017). Comparing applicants and incumbents: Effects of response distortion on mean scores and validity of personality measures. International Journal of Selection and Assessment, 25(3), 311-315. doi:https://doi.org/10.1111/ijsa.12182

John, O. P., \& Robins, R. W. (1993). Determinants of interjudge agreement on personality traits: The Big Five domains, observability, evaluativeness, and the unique perspective of the self. Journal of Personality, 61(4), 521-551. doi:https://doi.org/10.1111/j.1467-6494.1993.tb00781.x

John, O. P., \& Robins, R. W. (1994). Accuracy and bias in self-perception: individual differences in self-enhancement and the role of narcissism. Journal of Personality and Social Psychology, 66(1), 206-219. doi:https://doi.org/10.1037/00223514.66.1.206

Just, C. (2011). A review of literature on the general factor of personality. Personality and Individual Differences, 50(6), 765-771. doi:https://doi.org/10.1016/j.paid.2011.01.008

Kam, C. (2013). Probing item social desirability by correlating personality items with Balanced Inventory of Desirable Responding (BIDR): A validity examination. Personality and Individual Differences, 54(4), 513-518. doi:https://doi.org/10.1016/j.paid.2012.10.017

Leising, D., Burger, J., Zimmermann, J., Bäckström, M., Oltmanns, J. R., \& Connelly, B. S. (2020). Why do items correlate with one another? A conceptual analysis with relevance for general factors and network models. doi:https://doi.org/10.31234/osf.io/7c895

Leising, D., Ostrovski, O., \& Borkenau, P. (2012). Vocabulary for describing disliked persons is more differentiated than vocabulary for describing liked persons. Journal of Research in Personality, 46(4), 393-396. doi:https://doi.org/10.1016/j.jrp.2012.03.006

Leising, D., Scherbaum, S., Locke, K. D., \& Zimmermann, J. (2015). A model of “substance" and "evaluation" in person judgments. Journal of Research in Personality, 57, 61-71. doi:https://doi.org/10.1016/j.jrp.2015.04.002 
Leising, D., Vogel, D., Waller, V., \& Zimmermann, J. (2020). Correlations between person-descriptive items are predictable from the product of their mid-point-centered social desirability values. European Journal of Personality, 0890207020962331.

Loevinger, J. (1954). The attenuation paradox in test theory. Psychological Bulletin, 51(5), 493-504. doi:https://doi.org/10.1037/h0058543

MacCann, C., Pearce, N., \& Jiang, Y. (2017). The general factor of personality is stronger and more strongly correlated with cognitive ability under instructed faking. Journal of Individual Differences, 38(1), 46-54. doi:https://doi.org/10.1027/1614-0001/a000221

McCrae, R. R., \& Costa, P. T. (1983). Social desirability scales: More substance than style. Journal of consulting and clinical psychology, 51(6), 882.

McCrae, R. R., \& John, O. P. (1992). An introduction to the five-factor model and its applications. Journal of Personality, 60(2), 175-215. doi:https://doi.org/10.1111/j.1467-6494.1992.tb00970.x

McCrae, R. R., \& Mõttus, R. (2019). What personality scales measure: A new psychometrics and its implications for theory and assessment. Current Directions in Psychological Science, $28(4), \quad 415-420$. doi:https://doi.org/10.1177/0963721419849559

Mcfarland, L. A. (2003). Warning against faking on a personality test: Effects on applicant reactions and personality test scores. International Journal of Selection and Assessment, 11(4), 265-276. doi:https://doi.org/10.1111/j.0965075X.2003.00250.x

McFarland, L. A., \& Ryan, A. M. (2000). Variance in faking across noncognitive measures. Journal of Applied Psychology, 85(5), 812.

McNeish, D. (2018). Thanks coefficient alpha, we'll take it from here. Psychological Methods, $23(3), 412-433$. doi:https://doi.org/10.1037/met0000144

Morgeson, F. P., Campion, M. A., Dipboye, R. L., Hollenbeck, J. R., Murphy, K., \& Schmitt, N. (2007). Reconsidering the use of personality tests in personnel selection contexts. Personnel Psychology, 60(3), 683-729. doi:https://doi.org/10.1111/j.1744-6570.2007.00089.x

Mueller-Hanson, R., Heggestad, E. D., \& Thornton III, G. C. (2003). Faking and selection: Considering the use of personality from select-in and select-out perspectives. Journal of Applied Psychology, 88(2), 348-355. doi:https://doi.org/10.1037/00219010.88.2.348

Musek, J. (2007). A general factor of personality: Evidence for the Big One in the five-factor model. Journal of Research in Personality, 41(6), 1213-1233. doi:https://doi.org/10.1016/j.jrp.2007.02.003

Nederhof, A. J. (1985). Methods of coping with social desirability bias: A review. European Journal of Social Psychology, 15(3), 263-280. doi:https://doi.org/10.1002/ejsp.2420150303

Ones, D. S., Viswesvaran, C., \& Reiss, A. D. (1996). Role of social desirability in personality testing for personnel selection: The red herring. Journal of Applied Psychology, 81(6), 660-679. doi:https://doi.org/10.1037/0021-9010.81.6.660

Paulhus, D. L. (1984). Two-component models of socially desirable responding. Journal of Personality and Social Psychology, 46(3), 598-609. doi:https://doi.org/10.1037/0022-3514.46.3.598

Paunonen, S. V., \& LeBel, E. P. (2012). Socially desirable responding and its elusive effects on the validity of personality assessments. Journal of Personality and Social Psychology, 103(1), 158.

Peabody, D. (1967). Trait inferences: Evaluative and descriptive aspects. Journal of Personality and Social Psychology, 7(4p2), 118. doi:https://doi.org/10.1037/h0025230

Peabody, D. (1984). Personality dimensions through trait inferences. Journal of Personality and Social Psychology, 46(2), 384403. doi:https://doi.org/10.1037/0022-3514.46.2.384

Peabody, D., \& Goldberg, L. R. (1989). Some determinants of factor structures from personality-trait descriptors. Journal of Personality and Social Psychology, 57(3), 552-567. doi:https://doi.org/10.1037/0022-3514.57.3.552

Pettersson, E., Turkheimer, E., Horn, E. E., \& Menatti, A. R. (2012). The general factor of personality and evaluation. European Journal of Personality, 26(3), 292-302. doi:https://doi.org/10.1002/per.839

Phillips, D. L., \& Clancy, K. J. (1972). Some effects of" social desirability" in survey studies. American Journal of Sociology, 77(5), 921-940. doi:https://doi.org/10.1086/225231

Reise, S. P., Moore, T. M., \& Haviland, M. G. (2010). Bifactor models and rotations: Exploring the extent to which multidimensional data yield univocal scale scores. Journal of Personality Assessment, 92(6), 544-559. doi:https://doi.org/10.1080/00223891.2010.496477

Revelle, W., \& Wilt, J. (2013). The general factor of personality: A general critique. Journal of Research in Personality, 47(5), 493-504. doi:https://doi.org/10.1016/j.jrp.2013.04.012

Rothstein, M. G., \& Goffin, R. D. (2006). The use of personality measures in personnel selection: What does current research support? Human Resource Management Review, 16(2), 155-180. doi:https://doi.org/10.1016/j.hrmr.2006.03.004

Saucier, G. (2002). Orthogonal markers for orthogonal factors: The case of the Big Five. Journal of Research in Personality, 36(1), 1-31. doi:https://doi.org/10.1006/jrpe.2001.2335

Schmit, M. J., \& Ryan, A. M. (1993). The Big Five in personnel selection: Factor structure in applicant and nonapplicant populations. Journal of Applied Psychology, 78(6), 966-974. doi:https://doi.org/10.1037/0021-9010.78.6.966

Schmitt, N., \& Oswald, F. L. (2006). The impact of corrections for faking on the validity of noncognitive measures in selection settings. Journal of Applied Psychology, 91(3), 613-621. doi:https://doi.org/10.1037/0021-9010.91.3.613

Steiger, J. H. (1980). Tests for comparing elements of a correlation matrix. Psychological Bulletin, 87(2), $245-251$. doi:https://doi.org/10.1037/0033-2909.87.2.245 
Tett, R. P., Jackson, D. N., \& Rothstein, M. (1991). Personality measures as predictors of job performance: a meta-analytic review. Personnel Psychology, 44(4), 703-742. doi:https://doi.org/10.1111/j.1744-6570.1991.tb00696.x

Topping, G. D., \& O'Gorman, J. (1997). Effects of faking set on validity of the NEO-FFI. Personality and Individual Differences, 23(1), 117-124. doi:https://doi.org/10.1016/s0191-8869(97)00006-8

Uziel, L. (2010). Rethinking social desirability scales: From impression management to interpersonally oriented self-control. Perspectives on Psychological science, 5(3), 243-262. doi:https://doi.org/10.1177/1745691610369465

van der Linden, D., Dunkel, C. S., \& Petrides, K. (2016). The General Factor of Personality (GFP) as social effectiveness: Review of the literature. Personality and Individual Differences, 101, 98-105. doi:https://doi.org/10.1016/j.paid.2016.05.020

van der Linden, D., Pekaar, K. A., Bakker, A. B., Schermer, J. A., Vernon, P. A., Dunkel, C. S., \& Petrides, K. (2017). Overlap between the general factor of personality and emotional intelligence: A meta-analysis. Psychological Bulletin, 143(1), 36-52. doi:https://doi.org/10.1037/bul0000078

Van der Linden, D., te Nijenhuis, J., \& Bakker, A. B. (2010). The general factor of personality: A meta-analysis of Big Five intercorrelations and a criterion-related validity study. Journal of Research in Personality, 44(3), 315-327. doi:https://doi.org/10.1016/j.jrp.2010.03.003

Wessels, N. M., Zimmermann, J., Biesanz, J. C., \& Leising, D. (2020). Differential associations of knowing and liking with accuracy and positivity bias in person perception. Journal of Personality and Social Psychology, 118(1), $149-171$. doi:https://doi.org/10.1037/pspp0000218

West, T. V., \& Kenny, D. A. (2011). The truth and bias model of judgment. Psychological Review, 118(2), 357.

Worthington, D. L., \& Schlottmann, R. S. (1986). The predictive validity of subtle and obvious empirically derived psychological test items under faking conditions. Journal of Personality Assessment, 50(2), $171-181$. doi:https://doi.org/10.1207/s15327752jpa5002 2

Zickar, M. J., \& Robie, C. (1999). Modeling faking good on personality items: An item-level analysis. Journal of Applied Psychology, 84(4), 551-563. doi:https://doi.org/10.1037/0021-9010.84.4.551

\section{Table 1}

Scale Correlations and Descriptive Statistics for Standard IPIP NEO and LEFFI

\begin{tabular}{|c|c|c|c|c|c|c|c|c|c|c|}
\hline Factor & 1 & 2 & 3 & 4 & 5 & 6 & 7 & 8 & 9 & 10 \\
\hline \multicolumn{11}{|l|}{ Standard IPIP NEO } \\
\hline \multicolumn{11}{|l|}{ 1. Neuroticism } \\
\hline 2. Extraversion & -.36 & & & & & & & & & \\
\hline 3. Openness & -.05 & .20 & & & & & & & & \\
\hline 4. Agreeableness & -.34 & .11 & .11 & & & & & & & \\
\hline 5. Conscientiousness & -.36 & .21 & .00 & .21 & & & & & & \\
\hline \multicolumn{11}{|l|}{ Neutralized } \\
\hline 6. Neuroticism & .81 & -.35 & -.01 & -.26 & -.32 & & & & & \\
\hline 7. Extraversion & -.30 & .83 & .17 & .00 & .14 & -.33 & & & & \\
\hline 8. Openness & .07 & .07 & .78 & .02 & -.12 & .08 & .06 & & & \\
\hline 9. Agreeableness & -.20 & .04 & .06 & .71 & .09 & -.20 & -.04 & .06 & & \\
\hline 10. Conscientiousness & -.23 & .11 & -.09 & .11 & .77 & -.29 & .09 & -.15 & .11 & \\
\hline \multicolumn{11}{|l|}{ Descriptive Statistics } \\
\hline$M$ & 2.93 & 3.27 & 3.81 & 3.77 & 3.46 & 3.46 & 2.82 & 3.29 & 3.13 & 2.86 \\
\hline$S D$ & 0.73 & 0.69 & .53 & .49 & .61 & .59 & .64 & .53 & .56 & .59 \\
\hline Retest Reliability & .90 & .90 & .91 & .86 & .88 & .85 & .89 & .87 & .84 & .89 \\
\hline Cronbach's $\alpha$ & .87 & .87 & .75 & .74 & .83 & .82 & .83 & .74 & .75 & .81 \\
\hline
\end{tabular}

Note. $n=3,164 . r=.04, p<.05 ; r=.05, p<.01 ; r=.06, p<.001$. Significant correlations $p<0.05$ in bold.

Standard with neutralized same scale correlations are italicized in lower left diagonal. Retest Reliability $n=213$, all significant at $\mathrm{p}<.001$ (if $r \geq .22$ ).

LEFFI $=$ Less Evaluative Five Factor Inventory. 
Table 2

\section{Criterion Descriptive Statistics and Correlations with Big Five Personality}

\begin{tabular}{|c|c|c|c|c|c|c|c|c|c|c|c|c|c|c|}
\hline \multirow[t]{2}{*}{ Criterion } & \multirow[t]{2}{*}{$M$} & \multirow[t]{2}{*}{$S D$} & \multicolumn{2}{|c|}{ Neuroticism } & \multicolumn{2}{|c|}{ Extraversion } & \multicolumn{2}{|c|}{ Openness } & \multicolumn{2}{|c|}{ Agree. } & \multicolumn{2}{|c|}{ Consc. } & \multirow{2}{*}{$\begin{array}{c}\text { Adj } \\
R \\
\text { St }\end{array}$} & \multirow{2}{*}{$\begin{array}{c}\text { Adj } \\
R \\
\mathrm{Ne}\end{array}$} \\
\hline & & & St & $\mathrm{Ne}$ & St & $\mathrm{Ne}$ & $\mathrm{St}$ & $\mathrm{Ne}$ & $\mathrm{St}$ & $\mathrm{Ne}$ & $\mathrm{St}$ & $\mathrm{Ne}$ & & \\
\hline \multicolumn{15}{|l|}{ Self-reported criteria } \\
\hline University Grade & 72.80 & 9.82 & -.05 & .05 & .01 & -.03 & .10 & .06 & .05 & .01 & $.23 *$ & .13 & $.26 *$ & .18 \\
\hline Smoker & .09 & .29 & .06 & .04 & .07 & .06 & .08 & .08 & -.05 & -.03 & -.06 & -.06 & .14 & .11 \\
\hline Alcohol Consumption & 2.39 & 1.02 & .03 & .04 & .17 & .16 & .03 & .02 & -.02 & -.03 & -.07 & $-.13 *$ & .21 & .22 \\
\hline Exercise Frequency & 3.04 & 2.43 & -.13 & -.14 & .14 & .14 & .05 & -.03 & .06 & .05 & .20 & .17 & .22 & .22 \\
\hline Get-up Lateness & 9:07am & $1.72 \mathrm{~h}$ & $.22 *$ & .18 & $-.11 *$ & -.06 & -.04 & .03 & $-.13 *$ & -.07 & $-.30 *$ & -.24 & $.32 *$ & .26 \\
\hline Donated Blood & .12 & .32 & -.01 & -.02 & .04 & .02 & .02 & .00 & .01 & -.01 & .02 & .01 & .00 & .00 \\
\hline Dental Brushing Frequency & 4.41 & 1.04 & -.09 & -.07 & .09 & .06 & .01 & -.03 & .07 & .04 & .18 & .15 & .18 & .15 \\
\hline Has Tattoo & .37 & .48 & .06 & .05 & $.09 *$ & .04 & .09 & .10 & -.03 & -.05 & .04 & .00 & .16 & .12 \\
\hline Played Instrument & .26 & .44 & -.01 & -.01 & .05 & .05 & .19 & .21 & .01 & .00 & -.05 & -.08 & .20 & .21 \\
\hline Religious Worship & 1.69 & 1.06 & -.11 & -.10 & .04 & .03 & -.10 & -.11 & .06 & .07 & .01 & .01 & .16 & .15 \\
\hline Attended Heavy Metal & .22 & .41 & .03 & .01 & .04 & .02 & .22 & .21 & -.05 & -.06 & -.03 & -.03 & .23 & .22 \\
\hline Atte & .40 & .49 & -.02 & .02 & $.11 *$ & .07 & .16 & .14 & .07 & .02 & $.07 *$ & .01 & .19 & .15 \\
\hline Atte & .82 & .39 & -.07 & -.07 & $.16 *$ & .11 & -.01 & -.06 & .07 & .04 & .06 & .02 & .17 & .13 \\
\hline Publicly Protested & .25 & .43 & .02 & .02 & .12 & .11 & .35 & .33 & .01 & -.02 & -.05 & $-.10 *$ & .36 & .34 \\
\hline Female & .82 & .39 & .15 & .18 & -.01 & -.06 & -.07 & -.06 & .11 & .08 & .11 & .09 & .29 & .27 \\
\hline Age & 25.66 & 8.57 & $-.20 *$ & -.12 & .02 & -.03 & $.11 *$ & .07 & $.07 *$ & -.01 & $.14 *$ & .07 & $.24 *$ & .18 \\
\hline \multicolumn{15}{|l|}{ Other-reported criteria } \\
\hline Talkativeness & 3.40 & 0.69 & -.05 & -.07 & .53 & .51 & .05 & .01 & -.06 & -.09 & .06 & .03 & .56 & .51 \\
\hline 1 Dominance & 3.35 & 0.57 & -.10 & -.12 & .45 & .45 & $.12 \%$ & .06 & -.09 & -.13 & .08 & .04 & .48 & .45 \\
\hline Hun & 3.55 & 0.6 & -.07 & -.10 & .41 & .40 & .10 & .06 & -.04 & -.04 & -.03 & -.05 & .43 & .41 \\
\hline Infor & 3.47 & 4.67 & -.16 & -.11 & $.36^{*}$ & .29 & .11 & .06 & .12 & .06 & .03 & -.05 & $.38 *$ & .32 \\
\hline -Humility & 3.73 & 0.45 & $-.13 *$ & -.06 & -.12 & -.15 & -.01 & -.01 & .26 & .20 & $.12 *$ & .06 & .31 & .25 \\
\hline Emo & 3.35 & 0.48 & .37 & .40 & -.03 & -.07 & -.08 & -.02 & .08 & .12 & -.04 & .02 & .46 & .46 \\
\hline Extr & 3.43 & 0.51 & -.41 & -.38 & $.62 *$ & .56 & .08 & -.03 & .11 & .06 & $.16 *$ & .06 & $.66^{*}$ & .60 \\
\hline Agre & & & -.22 & -.19 & -.04 & -.07 & -.02 & & .42 & .44 & .01 & -.03 & .45 & .47 \\
\hline Cons & 3.74 & 0.48 & $-.12 *$ & -.05 & -.05 & -.08 & -.07 & -.11 & .08 & .04 & $.50 *$ & .44 & $.52 *$ & .45 \\
\hline Openness & 3.51 & 0.53 & -.06 & -.05 & .08 & .05 & .62 & .57 & .02 & .01 & -.03 & $-.09 *$ & .62 & .58 \\
\hline Cognitive Ability & 63.3 & 21.1 & -.03 & .05 & -.16 & -.21 & .13 & .07 & .10 & .05 & -.03 & -.09 & .24 & .23 \\
\hline $\begin{array}{l}\text { Mean of absolute corre } \\
\text { for self-reported criteri }\end{array}$ & & & .08 & .07 & .08 & .06 & .10 & .10 & .05 & .04 & .10 & .08 & .21 & .18 \\
\hline $\begin{array}{l}\text { Mean of absolute correlations } \\
\text { for other-reported criteria }\end{array}$ & & & .17 & .15 & .27 & .26 & .13 & .09 & .13 & .12 & .11 & .09 & .49 & .45 \\
\hline $\begin{array}{l}\text { Mean of all absolute } \\
\text { correlations }\end{array}$ & & & .11 & .10 & .15 & .14 & .11 & .09 & .08 & .07 & .10 & .08 & .31 & .28 \\
\hline \multicolumn{15}{|c|}{$\begin{array}{l}\text { Note. Self-report criteria }(n=2,910 \text { to } 3,164), r=.04, p<.05 ; r=.05, p<.01 ; r=.06, p<.001 ; \text { other-rated } \\
\text { communication styles }(n=1,116), r=.06, p<.05 ; r=.08, p<.01 ; r=.10, p<.001 ; \text { other-rated HEXACO (n= } \\
1,356), r=.05, p<.05 ; r=.07, p<.01 ; r=.09, p<.001 ; \text { cognitive ability }(n=649) r=.08, p<.05 ; r=.10, p< \\
.01 ; r=.13, p<.001 \text {. Agree. = agreeableness, Consc. = conscientiousness. St = Standard; Ne = Neutralized (LEFFI). } \\
\text { Bivariate correlations } \geq .10 \text { are in bold. Significant Adj } \mathrm{R} \text { 's } \geq .20 \text { are in bold. All Adj R's are significant at } p<.05 \\
\text { except donated blood. }\end{array}$} \\
\hline & & & & & & & & & & & & & & \\
\hline
\end{tabular}




\section{Figure 1}

\section{Conceptual Model of the Influence of Social Desirability on Self-Rated Item Responses}

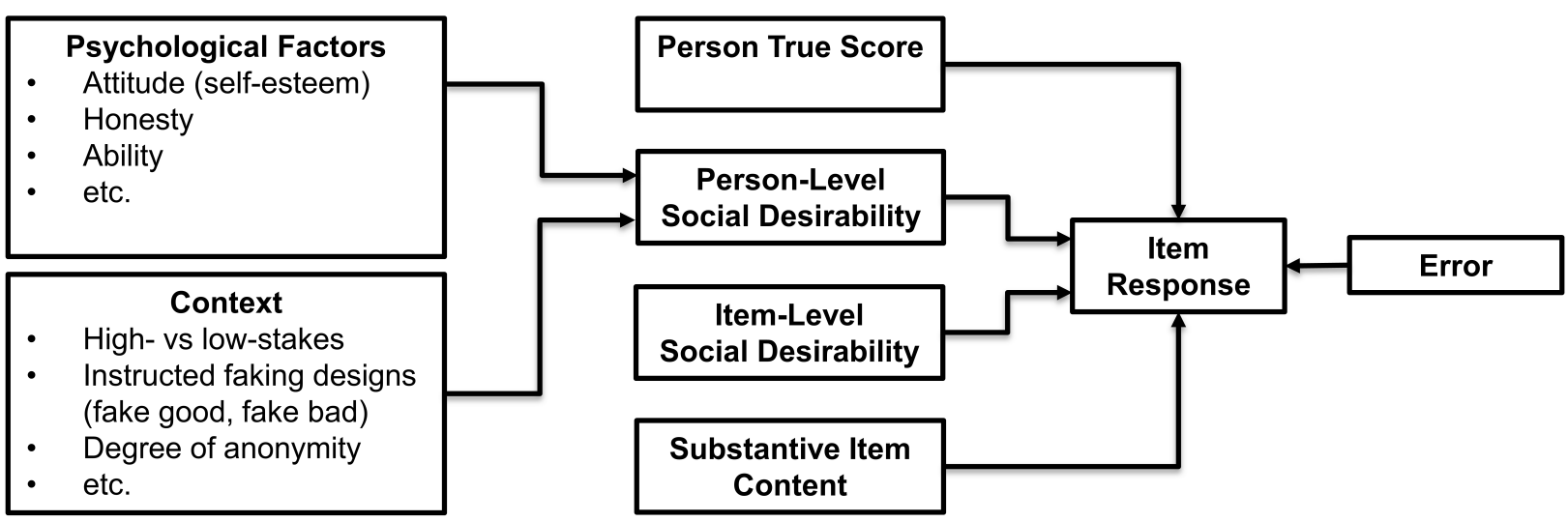

\section{Appendix}

\section{Table A1}

\section{Self-Report Outcome Criteria}

\begin{tabular}{|c|c|c|}
\hline Outcome Measure Label & Question Text & Options \\
\hline University Grade & $\begin{array}{l}\text { What is your average grade for all units that you have } \\
\text { completed in the last semester? }\end{array}$ & $0 ; 1 \% ; 2 \% \ldots 99 \% ; 100 \%$ \\
\hline Smoker & $\begin{array}{l}\text { How many cigarettes did you smoke per day over the last } \\
\text { week? }\end{array}$ & $\begin{array}{l}\text { None; } 1-2 ; 3-5 ; 6-10 ; 11-15 ; 16-20 ; 21-25 \text {; } \\
26-30 ; 31 \text { or more (cigarettes per day) }\end{array}$ \\
\hline Alcohol Consumption & $\begin{array}{l}\text { Do you consider yourself a non-drinker, infrequent drinker, } \\
\text { light drinker, moderate drinker, or heavy drinker of alcohol? }\end{array}$ & $\begin{array}{l}\text { non-drinker; infrequent drinker; light } \\
\text { drinker; moderate drinker; heavy drinker }\end{array}$ \\
\hline Exercise Frequency & $\begin{array}{l}\text { How many times per week do you exercise, on average (e.g., } \\
\text { sport, weights, running, swimming, fitness class)? }\end{array}$ & $\begin{array}{l}\text { less than once; } 1 ; 2 ; 3 \ldots 20 ; 21 ; \text { more than } \\
21 \text { (times per week) }\end{array}$ \\
\hline Get-up Lateness & $\begin{array}{l}\text { By what time do you typically get out of bed on a non-work } \\
\text { day? }\end{array}$ & $\begin{array}{l}\text { Earlier than 4:00AM; 4:00AM; } \\
\text { 4:30AM...3:30PM; 4:00PM; Later than } \\
\text { 4:00PM }\end{array}$ \\
\hline Donated Blood & Have you donated blood in the past 24 months ( 2 years)? & Yes/No \\
\hline Dental Brushing Frequency & On average, how many times per day do you brush your teeth? & $\begin{array}{l}\text { never; less than once; once; once or twice; } \\
\text { twice; two or three times; three times; } \\
\text { more than three times (per day) }\end{array}$ \\
\hline Has Tattoo & How many tattoos do you have? & none; $1 ; 2 ; 3-5 ; 6-10 ; 11$ or more \\
\hline Played Instrument & Have you played a musical instrument in the last month? & Yes/No \\
\hline $\begin{array}{l}\text { Attended Place of Religious } \\
\text { Worship }\end{array}$ & $\begin{array}{l}\text { Thinking about the last few years, how often do you go to a } \\
\text { place of religious worship? }\end{array}$ & $\begin{array}{l}\text { A } 5 \text {-point scale where } 1=\mathrm{I} \text { do not ever go } \\
\text { to a place of worship; } 5=\mathrm{I} \text { go to a place of } \\
\text { worship very frequently (every week to a } \\
\text { few times per week) }\end{array}$ \\
\hline Attended Heavy Metal & Have you ever been to a heavy metal concert? & Yes/No \\
\hline Attended Ballet & Have you ever been to a ballet performance? & Yes/No \\
\hline Attended Football & $\begin{array}{l}\text { Have you ever been to a live football match (e.g., rugby, AFL, } \\
\text { soccer, etc.)? }\end{array}$ & Yes/No \\
\hline Publicly Protested & Have you ever attended a public protest? & Yes/No \\
\hline Female & Sex & Male; Female; Other; Prefer not to answer \\
\hline Age & Age & $18 ; 19 ; 20 \ldots 101 ; 102$ \\
\hline
\end{tabular}


Table A2

Less Evaluative Five Factor Inventory (LEFFI)

\begin{tabular}{|c|c|c|}
\hline Item Text & $\begin{array}{l}\text { Factor } \\
\text { Loading }\end{array}$ & $\begin{array}{l}\text { Mean Social } \\
\text { Desirability }\end{array}$ \\
\hline \multicolumn{3}{|l|}{ Neuroticism } \\
\hline 1. I sometimes feel flat. & 0.64 & -0.63 \\
\hline 2. I dislike some aspects of myself. & 0.57 & -0.25 \\
\hline 3. I am at times low in mood. & 0.65 & -0.87 \\
\hline 4. My mood is often affected by unwelcome events. & 0.69 & -1.31 \\
\hline 5. I become flustered when things go very wrong. & 0.68 & -0.97 \\
\hline 6. I rarely get frustrated even when situations depart from the ideal. (R) & 0.57 & 1.64 \\
\hline 7. I seldom feel sad, even in bad situations. (R) & 0.52 & 0.13 \\
\hline 8. I am very content with myself. (R) & 0.49 & 2.01 \\
\hline 9. I am hardly bothered by most things. (R) & 0.66 & 1.47 \\
\hline 10. I am very pleased with myself, having few shortcomings. (R) & 0.40 & 0.10 \\
\hline \multicolumn{3}{|l|}{ Extraversion $\mathrm{r}$ (a) } \\
\hline 11. I like being around people as much as I can. & 0.63 & 1.63 \\
\hline 12. I like frequently making new friends. & 0.65 & 1.90 \\
\hline 13. I enjoy navigating tricky social situations. & 0.56 & 1.58 \\
\hline 14. I am socially dominant at parties. & 0.77 & 0.00 \\
\hline 15. I don't mind drawing attention to myself. & 0.74 & 0.08 \\
\hline 16. I hold back my opinions. (R) & 0.45 & -0.35 \\
\hline 17. I am comfortable staying in the background in group situations. (R) & 0.67 & -0.43 \\
\hline 18. I would describe my experiences as fairly unexciting. (R) & 0.35 & -1.09 \\
\hline 19. I prefer not to do things that draw attention to myself. (R) & 0.70 & 0.36 \\
\hline 20. I am comfortable letting others do more of the talking. (R) & 0.56 & 0.12 \\
\hline \multicolumn{3}{|l|}{ Openness } \\
\hline 21. I believe that art is at least as important as practical matters. & 0.51 & 0.25 \\
\hline 22. I have a wild imagination. & 0.45 & 0.97 \\
\hline 23. I identify with left-wing political views. & 0.39 & 0.61 \\
\hline 24. I prefer conversing about abstract ideas rather than practical matters. & 0.54 & 0.37 \\
\hline 25. I enjoy hearing unconventional ideas. & 0.53 & 1.73 \\
\hline 26. I am more interested in the physical world than abstract ideas. (R) & 0.69 & 0.36 \\
\hline 27. I am less interested in looking at art than doing other activities. (R) & 0.62 & 0.00 \\
\hline 28. I am not especially interested in philosophical ideas. (R) & 0.66 & -0.67 \\
\hline 29. I prefer doing hands-on activities to going to art galleries. (R) & 0.48 & 0.71 \\
\hline 30. I hold somewhat conservative political views. (R) & 0.41 & -0.47 \\
\hline \multicolumn{3}{|l|}{ Agreeableness } \\
\hline 31. I have a good word even for bad people. & 0.60 & 1.86 \\
\hline 32. I believe others have good intentions even to the point that I am sometimes overly trusting. & 0.58 & 0.38 \\
\hline 33. I respect others, even if they are disrespectful towards me. & 0.63 & 1.77 \\
\hline 34. I accept people unreservedly rather than viewing their shortcomings with a critical eye. & 0.59 & 1.90 \\
\hline 35. I prefer to make people feel at ease than express my true opinion. & 0.48 & 0.43 \\
\hline 36. I am sometimes blunt in my communication. (R) & 0.47 & -0.96 \\
\hline 37. I sometimes make cutting remarks to others. (R) & 0.50 & -2.28 \\
\hline 38. I suspect that the motives of others are not always pure. (R) & 0.38 & -0.73 \\
\hline 39. I am unfriendly to people who have been unkind to me. (R) & 0.58 & -1.06 \\
\hline 40. I am sometimes impolite to people. (R) & 0.51 & -1.95 \\
\hline \multicolumn{3}{|l|}{ Conscientiousness } \\
\hline 41. I am always prepared well ahead of all situations. & 0.67 & 2.04 \\
\hline 42. I would choose to spend a fair part of my day ensuring the details are right. & 0.53 & 0.62 \\
\hline 43. I start boring but necessary tasks immediately. & 0.58 & 1.75 \\
\hline 44. I always carry out my plans. & 0.69 & 2.26 \\
\hline 45. I stick to my plans, regardless. & 0.66 & 1.04 \\
\hline 46. I waste some of my time. (R) & 0.57 & -1.39 \\
\hline 47. Sometimes it takes me longer to start mundane tasks. (R) & 0.52 & -0.93 \\
\hline 48. I sometimes only do the work needed to get by. (R) & 0.66 & -1.65 \\
\hline 49. I tend not to complete tasks if I feel the effort is no longer justified. (R) & 0.51 & -1.06 \\
\hline 50. I skip some of my duties. (R) & 0.64 & -1.99 \\
\hline
\end{tabular}

Note. The LEFFI was adapted from the IPIP NEO. It is licensed CC0 1.0 Universal (CC0 1.0) Public Domain. Items and factor loadings are for the main study measure. $\mathrm{R}=$ items to be reverse scored. Response scale is $1=$ Strongly Disagree, $2=$ Disagree, $3=$ Neutral (neither agree nor disagree), $4=$ Agree, and $5=$ Strongly Agree. Factor loading is the primary factor loading based on principal component analysis with promax rotation. Mean social desirability is centered at zero based on deviation from neutral midpoint of 4 on a 1 to 7 social desirability scale. 


\section{Online Supplement}

\subsection{Pilot Study}

To develop an evaluatively neutralized questionnaire, two potential neutralized items were created for each standard item from the 50-item IPIP NEO. The following strategies were applied in order to neutralize items: (a) include a more evaluatively neutral trait term within the item (e.g., "I often feel blue" changed to "I sometimes feel flat"); (b) ask about more moderate rather than extreme levels of traits, where the extreme level is socially desirable or undesirable (e.g., "I panic easily" to "I become flustered when things go very wrong"); (c) ask about more extreme levels of traits where a moderate level is socially desirable and a more extreme level may even be less credible to agree with (e.g., "I pay attention to details" to "I would choose to spend a fair part of my day ensuring the details are right"); (d) include interpersonal behaviors that are more socially acceptable and less extreme (e.g., "I get back at others" to "I am unfriendly to people who have been unkind to me"); (e) change frequency to make it less confronting to agree with and also less credible to strongly disagree with (e.g., "I often feel blue" changed to "I sometimes feel flat"); (f) change skills or abilities which are socially desirable to preferences (e.g., "I make friends easily" to "I like frequently making new friends"); (g) use items that have potentially positive and negative social desirability elements, rather than no social desirability or one-sided social desirability elements (e.g., "I have little to say" to "I hold back my opinions"); (h) normalize an undesired response by adding a typical context, so that the behaviour is justified, it is more acceptable, and is less credible to strongly disagree with (e.g., "I seldom feel blue" changed to "I seldom feel sad, even in bad situations"); (i) contrast a desirable trait with another desirable trait that is somewhat opposite to it in reference to the factor being investigated, so that endorsement of one desirable trait is in effect disendorsement of the other trait (e.g., "I believe in the importance of art" to "I believe art is at least as important as practical matters"); (j) focus on negative aspects of the person rather than the whole person (e.g., "I dislike myself" to "I dislike some aspects of myself'); (k) reverse two aspects of an item to achieve the same meaning but try to reduce social desirability - although results revealed this approach to be problematic (e.g., "I feel comfortable around people" to "I feel uncomfortable when I am away from other people for extended periods"); (1) change connotation from avoidance or fear to a deliberate choice based on preference or taste (e.g., "I don't like to draw attention to myself" to "I prefer not to do things that draw attention to myself'); and (m) compare the importance of the interest or activity in the original item to other, generalized interests or activities (e.g., "I do not like art" to "I am less interested in looking at art than doing other activities").

In order to determine the best alternative of the two, to be used in the first iteration of the evaluatively neutralized questionnaire, two different ratings were used. First, the mean social desirability rating was calculated for all 150 items (50 standard items plus 100 alternatives), on a 7-point scale where $1=$ Very Unfavourable, 2 = Moderately Unfavourable, 3 = Slightly Unfavourable, $4=$ Neutral - neither favourable nor unfavourable, 5 = Slightly Favourable, $6=$ Moderately Favourable, and $7=$ Very Favourable. Second, for each of the two neutralized alternatives, its mean rated similarity in meaning to the standard item 
was calculated, based on a 5-point scale, where $1=$ Not similar at all, $2=$ Only slightly similar, $3=$ Moderately similar, $4=$ Very similar, and $5=$ Extremely similar . Table S1 shows the results. Note, for ease of interpretation, Table S1 shows social desirability means based on raw scores that have not been reversed. 
Table S1

Rated Social Desirability and Similarity of Items

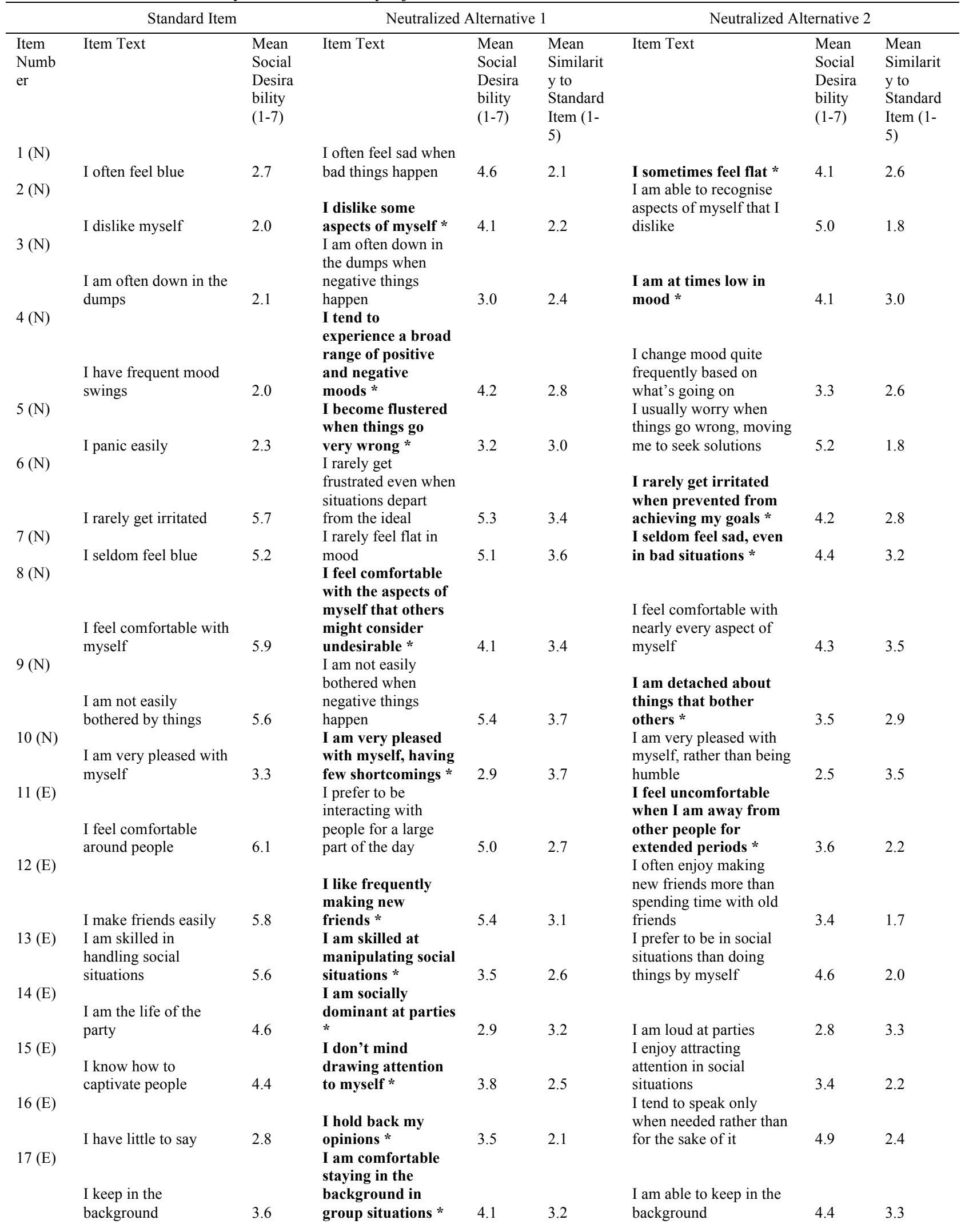




\begin{tabular}{|c|c|c|c|c|c|c|c|c|}
\hline $18(\mathrm{E})$ & $\begin{array}{l}\text { I would describe my } \\
\text { experiences as }\end{array}$ & & $\begin{array}{l}\text { I would describe } \\
\text { my life experiences }\end{array}$ & & & I live a fairly risk-free & & \\
\hline & somewhat dull & 3.0 & as fairly typical * & 4.0 & 2.3 & life & 4.1 & 2.2 \\
\hline $19(\mathrm{E})$ & I don't like to draw & & $\begin{array}{l}\text { I seldom like to } \\
\text { draw attention to }\end{array}$ & & & $\begin{array}{l}\text { I prefer not to do } \\
\text { things that draw }\end{array}$ & & \\
\hline $20(\mathrm{E})$ & attention to myself & 4.4 & Idon't dominate & 3.8 & 4.0 & $\begin{array}{l}\text { attention to myself * } \\
\text { I am comfortable }\end{array}$ & 4.2 & 4.3 \\
\hline $21(\mathrm{O})$ & I don't talk a lot & 3.4 & $\begin{array}{l}\text { I don't dominate } \\
\text { conversations } \\
\text { I believe that art is }\end{array}$ & 5.3 & 3.6 & $\begin{array}{l}\text { letting others do more } \\
\text { of the talking* } \\
\text { I believe that art is at }\end{array}$ & 4.6 & 3.0 \\
\hline & $\begin{array}{l}\text { I believe in the } \\
\text { importance of art }\end{array}$ & 5.0 & $\begin{array}{l}\text { very important to } \\
\text { society }\end{array}$ & 4.7 & 4.6 & $\begin{array}{l}\text { least as important as } \\
\text { practical matters * }\end{array}$ & 4.3 & 3.7 \\
\hline $22(\mathrm{O})$ & $\begin{array}{l}\text { I have a vivid } \\
\text { imagination }\end{array}$ & 5.5 & $\begin{array}{l}\text { I like to daydream } \\
*\end{array}$ & 4.3 & 3.2 & $\begin{array}{l}\text { I spend a lot of time } \\
\text { imagining possibilities }\end{array}$ & 4.7 & 3.6 \\
\hline $23(\mathrm{O})$ & $\begin{array}{l}\text { I tend to vote for left- } \\
\text { wing political } \\
\text { candidates }\end{array}$ & 4.9 & $\begin{array}{l}\text { I tend to support } \\
\text { left-wing political } \\
\text { candidates }\end{array}$ & 4.6 & 4.7 & $\begin{array}{l}\text { I identify with left-wing } \\
\text { political views * }\end{array}$ & 4.5 & 4.2 \\
\hline $24(\mathrm{O})$ & $\begin{array}{l}\text { I carry the } \\
\text { conversation to a }\end{array}$ & & $\begin{array}{l}\text { I prefer conversing } \\
\text { about abstract } \\
\text { ideas rather than }\end{array}$ & & & $\begin{array}{l}\text { I have an intellectual } \\
\text { rather than down-to- } \\
\text { earth conversational }\end{array}$ & & \\
\hline $25(\mathrm{O})$ & higher level & 3.9 & $\begin{array}{l}\text { practical matters * } \\
\text { I enjoy hearing }\end{array}$ & 3.9 & 2.4 & $\begin{array}{l}\text { style } \\
\text { I enjoy hearing exotic }\end{array}$ & 3.3 & 2.7 \\
\hline $26(\mathrm{O})$ & $\begin{array}{l}\text { I enjoy hearing new } \\
\text { ideas }\end{array}$ & 5.8 & $\begin{array}{l}\text { unconventional } \\
\text { ideas } \\
\text { I am more interested }\end{array}$ & 5.0 & 3.6 & $\begin{array}{l}\text { new ideas, even if } \\
\text { impractical * } \\
\text { I am more interested in }\end{array}$ & 4.8 & 3.2 \\
\hline $27(\mathrm{O})$ & $\begin{array}{l}\text { I am not interested in } \\
\text { abstract ideas }\end{array}$ & 3.1 & $\begin{array}{l}\text { in real things than } \\
\text { abstract ideas }\end{array}$ & 4.3 & 2.9 & $\begin{array}{l}\text { the physical world than } \\
\text { abstract ideas * } \\
\text { I am less interested in }\end{array}$ & 4.2 & 2.8 \\
\hline $28(\mathrm{O})$ & I do not like art & 2.4 & $\begin{array}{l}\text { I like art less than } \\
\text { other things in life } \\
\text { I prefer real-world }\end{array}$ & 4.2 & 2.3 & $\begin{array}{l}\text { looking at art than } \\
\text { doing other activities * } \\
\text { I prefer common-sense }\end{array}$ & 4.0 & 2.4 \\
\hline $29(\mathrm{O})$ & $\begin{array}{l}\text { I avoid philosophical } \\
\text { discussions }\end{array}$ & 3.4 & $\begin{array}{l}\text { discussions to } \\
\text { philosophical ones } \\
\text { I prefer doing }\end{array}$ & 4.5 & 2.9 & $\begin{array}{l}\text { discussions to academic } \\
\text { ones * }\end{array}$ & 4.3 & 3.7 \\
\hline $30(\mathrm{O})$ & $\begin{array}{l}\text { I do not enjoy going to } \\
\text { art museums } \\
\text { I tend to vote for }\end{array}$ & 3.5 & $\begin{array}{l}\text { hands-on activities } \\
\text { to going to art } \\
\text { galleries * } \\
\text { I tend to support }\end{array}$ & 4.4 & 3.1 & $\begin{array}{l}\text { I enjoy doing other } \\
\text { things more than going } \\
\text { to art galleries }\end{array}$ & 4.4 & 2.9 \\
\hline 30 (ए) & $\begin{array}{l}\text { conservative political } \\
\text { candidates }\end{array}$ & 2.9 & $\begin{array}{l}\text { right-wing political } \\
\text { candidates }\end{array}$ & 2.6 & 4.0 & $\begin{array}{l}\text { I hold right-of-centre } \\
\text { political views * }\end{array}$ & 3.3 & 3.8 \\
\hline 31 (A) & $\begin{array}{l}\text { I have a good word for } \\
\text { everyone }\end{array}$ & 5.7 & $\begin{array}{l}\text { I have a good word } \\
\text { even for bad people }\end{array}$ & 4.6 & 3.8 & $\begin{array}{l}\text { I don't notice people's } \\
\text { flaws * }\end{array}$ & 4.1 & 2.7 \\
\hline $32(\mathrm{~A})$ & I believe that others & & $\begin{array}{l}\text { I trust that others } \\
\text { nearly always have } \\
\text { my best interests at }\end{array}$ & & & $\begin{array}{l}\text { I believe others have } \\
\text { good intentions even to } \\
\text { the point that I am } \\
\text { sometimes overly }\end{array}$ & & \\
\hline 33 (A) & have good intentions & 5.6 & $\begin{array}{l}\text { heart * } \\
\text { I respect others, } \\
\text { even if they are }\end{array}$ & 4.1 & 3.8 & $\begin{array}{l}\text { trusting } \\
\text { I respect others, even if } \\
\text { they are disrespectful }\end{array}$ & 4.2 & 3.4 \\
\hline 34 (A) & I respect others & 6.3 & $\begin{array}{l}\text { impolite to me } \\
\text { I accept people } \\
\text { unreservedly }\end{array}$ & 5.6 & 3.7 & towards me * & 5.3 & 3.5 \\
\hline & $\begin{array}{l}\text { I accept people as they } \\
\text { are }\end{array}$ & 5.9 & $\begin{array}{l}\text { rather than } \\
\text { viewing their } \\
\text { shortcomings with } \\
\text { a critical eve * }\end{array}$ & & & $\begin{array}{l}\text { I accept annoying people } \\
\text { as they are rather than } \\
\text { wanting them to change } \\
\text { their behaviour }\end{array}$ & 4.8 & 4.0 \\
\hline 35 (A) & & 5.9 & $\begin{array}{l}\text { a critical eye * } \\
\text { I prefer to make } \\
\text { people feel at ease }\end{array}$ & 4.4 & 4.1 & & 4.8 & 4.0 \\
\hline $36(\mathrm{~A})$ & $\begin{array}{l}\text { I make people feel at } \\
\text { ease }\end{array}$ & 6.0 & $\begin{array}{l}\text { than express my } \\
\text { true opinion * } \\
\text { I am honest even if }\end{array}$ & 3.7 & 2.5 & $\begin{array}{l}\text { I try very hard to make } \\
\text { people feel at ease }\end{array}$ & 5.1 & 3.6 \\
\hline $37(\mathrm{~A})$ & I have a sharp tongue & 2.6 & $\begin{array}{l}\text { people sometimes } \\
\text { don't like it * } \\
\text { I enjoy winning }\end{array}$ & 4.4 & 2.8 & $\begin{array}{l}\text { I am sometimes blunt in } \\
\text { my communication }\end{array}$ & 3.5 & 3.0 \\
\hline $38(\mathrm{~A})$ & I cut others to pieces & 1.4 & $\begin{array}{l}\text { verbal arguments } \\
\text { against others } \\
\text { I suspect that others }\end{array}$ & 3.2 & 2.4 & $\begin{array}{l}\text { I argue my case in a } \\
\text { forceful manner * } \\
\text { I susnect that the }\end{array}$ & 3.9 & 2.3 \\
\hline & $\begin{array}{l}\text { I suspect hidden } \\
\text { motives in others }\end{array}$ & 2.8 & $\begin{array}{l}\text { have hidden } \\
\text { intentions }\end{array}$ & 2.8 & 4.5 & $\begin{array}{l}\text { motives of others are } \\
\text { not always pure * }\end{array}$ & 3.8 & 3.6 \\
\hline
\end{tabular}




\begin{tabular}{|c|c|c|c|c|c|c|c|c|}
\hline 39 (A) & & & $\begin{array}{l}\text { I am unfriendly to } \\
\text { people who have } \\
\text { been unkind to me }\end{array}$ & & & I remember when others & & \\
\hline $40(\mathrm{~A})$ & I get back at others & 1.8 & $*$ & 3.4 & 3.5 & $\begin{array}{l}\text { have done wrong by me } \\
\text { I am candid rather than }\end{array}$ & 3.5 & 2.6 \\
\hline $41(\mathrm{C})$ & I insult people & 1.1 & $\begin{array}{l}\text { I tell people off if } \\
\text { they deserve it * }\end{array}$ & 3.8 & 2.3 & $\begin{array}{l}\text { overly delicate with } \\
\text { people's feelings } \\
\text { I am reluctant to go }\end{array}$ & 3.6 & 1.9 \\
\hline $42(\mathrm{C})$ & I am always prepared & 5.7 & $\begin{array}{l}\text { I am uncomfortable } \\
\text { operating without a } \\
\text { clear plan } \\
\text { I would choose to }\end{array}$ & 3.8 & 2.8 & $\begin{array}{l}\text { into situations without } \\
\text { substantial preparation } \\
*\end{array}$ & 4.1 & 3.4 \\
\hline & I pay attention to & & $\begin{array}{l}\text { spend a fair part of } \\
\text { my day ensuring } \\
\text { the details are right }\end{array}$ & & & $\begin{array}{l}\text { I am meticulous with } \\
\text { details to the point that } \\
\text { others think I am }\end{array}$ & & \\
\hline $43(\mathrm{C})$ & details & 6.2 & $*$ & 4.4 & 3.7 & $\begin{array}{l}\text { pedantic } \\
\text { I get chores done right }\end{array}$ & 3.1 & 2.9 \\
\hline & $\begin{array}{l}\text { I get chores done right } \\
\text { away }\end{array}$ & 5.6 & $\begin{array}{l}\text { I get chores done } \\
\text { right away, even if } \\
\text { there are higher } \\
\text { priorities }\end{array}$ & 3.5 & 3.2 & $\begin{array}{l}\text { away, rather than } \\
\text { choosing a later time } \\
\text { based on my range of } \\
\text { priorities * }\end{array}$ & 4.6 & 3.6 \\
\hline $44(\mathrm{C})$ & I carry out my plans & 5.9 & $\begin{array}{l}\text { I prefer not to } \\
\text { change plans when } \\
\text { I have put them in } \\
\text { place* }\end{array}$ & 3.9 & 3.3 & $\begin{array}{l}\text { I prefer to carry out my } \\
\text { plans, rather than adapt } \\
\text { to the situation }\end{array}$ & 3.1 & 2.6 \\
\hline $45(\mathrm{C})$ & & & $\begin{array}{l}\text { I make plans and } \\
\text { stick to them, even }\end{array}$ & & & & & \\
\hline & $\begin{array}{l}\text { I make plans and stick } \\
\text { to them }\end{array}$ & 5.4 & $\begin{array}{l}\text { when other } \\
\text { opportunities } \\
\text { emerge * }\end{array}$ & 4.1 & 3.3 & $\begin{array}{l}\text { I am uncomfortable } \\
\text { changing plans once they } \\
\text { are set }\end{array}$ & 3.6 & 3.0 \\
\hline $47(\mathrm{C})$ & I waste my time & 2.0 & $\begin{array}{l}\text { Not all my time is } \\
\text { spent in productive } \\
\text { pursuits* } \\
\text { I take care of other }\end{array}$ & 4.8 & 2.5 & $\begin{array}{l}\text { I spend time doing what } \\
\text { I find fulfilling rather } \\
\text { than what I have to }\end{array}$ & 4.5 & 1.6 \\
\hline $48(\mathrm{C})$ & $\begin{array}{l}\text { I find it difficult to get } \\
\text { down to work }\end{array}$ & 2.7 & $\begin{array}{l}\text { things before } \\
\text { getting down to } \\
\text { work* } \\
\text { I prefer not to }\end{array}$ & 3.7 & 2.7 & $\begin{array}{l}\text { I sometimes get down to } \\
\text { work when I feel like it } \\
\text { rather than immediately } \\
\text { I don't let work take }\end{array}$ & 3.4 & 2.8 \\
\hline & $\begin{array}{l}\text { I do just enough work } \\
\text { to get by }\end{array}$ & 2.4 & $\begin{array}{l}\text { work so hard that I } \\
\text { get fatigued * }\end{array}$ & 3.7 & 2.7 & $\begin{array}{l}\text { away from my time with } \\
\text { friends and family }\end{array}$ & 5.7 & 1.8 \\
\hline 49 (C) & $\begin{array}{l}\text { I don't see things } \\
\text { through } \\
\text { I shirk my duties }\end{array}$ & 2.0 & $\begin{array}{l}\text { I see deadlines as } \\
\text { flexible, based on } \\
\text { my range of } \\
\text { priorities } \\
\text { I avoid rigidly }\end{array}$ & 3.1 & 2.3 & $\begin{array}{l}\text { I tend not to complete } \\
\text { tasks if I feel the effort } \\
\text { is no longer justified * }\end{array}$ & 3.8 & 2.1 \\
\hline & & 1.5 & $\begin{array}{l}\text { fulfilling every } \\
\text { single one of my } \\
\text { duties * }\end{array}$ & 4.0 & 2.7 & $\begin{array}{l}\text { I prioritise having an } \\
\text { enjoyable life over some } \\
\text { duties }\end{array}$ & 3.9 & 1.8 \\
\hline
\end{tabular}

Note. $N=10$. Social Desirability ratings have not been reversed. $\mathrm{N}=$ neuroticism, $\mathrm{E}=$ extraversion, $\mathrm{O}=$ openness, $\mathrm{A}=$ agreeableness, $\mathrm{C}=$ conscientiousness. * item in bold is the one initially selected from the two alternatives for the major pilot $(n=687)$, although some non-asterisked items were later used for the main study.

It can also be seen from Table S1 that for 46 of the 50 standard items, at least one of the two alternative items had a mean social desirability rating that was more neutral than the standard item. Regarding item similarity, of the 100 alternatives (two for each of the 50 standard items), 50 had a mean similarity under 3 (moderately similar). This included 25 items with a mean similarity rating under 2.5 , of which 7 had a mean similarity rating under 2 (only slightly similar).

In the next stage of development, the use of a large sample $(n=687)$ permitted re-evaluation of the success of neutralized item creation, both in regard to reduction of evaluativeness and each item's effectiveness in capturing its Big Five factor. In order to ascertain the quality of items, mean and standard deviation of selfrating, mean evaluativeness (with sign included to indicate whether it was desirable 
or undesirable), factor loading, corrected item-total correlation, difference between absolute evaluativeness of standard and neutral item pair, and correlation between standard and neutral item pair, were calculated. Table S2 shows the results. Note, for ease of interpretation in Table S2, mean self-ratings and social desirability ratings are based on raw scores - negative keyed items have not been reversed. 
Table S2

Standard and Neutralized Item Descriptive Statistics for Pilot Study

\begin{tabular}{|c|c|c|c|c|c|c|c|c|c|c|c|c|}
\hline & $\begin{array}{l}\text { Standar } \\
\text { d Item }\end{array}$ & & & & & $\begin{array}{l}\text { Neutralized } \\
\text { Item }\end{array}$ & & & & & $\begin{array}{l}\text { Relation } \\
\text { Standard } \\
\text { and } \\
\text { Neutral }\end{array}$ & \\
\hline $\begin{array}{l}\text { Item } \\
\text { Number }\end{array}$ & $\begin{array}{l}\text { Mean } \\
\text { Self- } \\
\text { rating }\end{array}$ & $\begin{array}{l}\text { SD } \\
\text { Self- } \\
\text { rating }\end{array}$ & $\begin{array}{l}\text { Mean } \\
\text { Social } \\
\text { Desirability }\end{array}$ & $\begin{array}{l}\text { Factor } \\
\text { Loading }\end{array}$ & $\begin{array}{l}\text { Corrected } \\
\text { Item- } \\
\text { Total } \\
\text { Correlati } \\
\text { on }\end{array}$ & $\begin{array}{l}\text { Mean Self- } \\
\text { rating }\end{array}$ & $\begin{array}{l}\text { SD Self- } \\
\text { rating }\end{array}$ & $\begin{array}{l}\text { Mean } \\
\text { Social } \\
\text { Desirabilit } \\
\text { y }\end{array}$ & $\begin{array}{l}\text { Factor } \\
\text { Loading }\end{array}$ & $\begin{array}{l}\text { Corrected } \\
\text { Item-Total } \\
\text { Correlatio } \\
\mathrm{n}\end{array}$ & $\begin{array}{l}\text { Standard } \\
\text { Evaluative } \\
\text { ness (abs) } \\
\text { - Neutral } \\
\text { Evaluative } \\
\text { ness (abs) }\end{array}$ & $\begin{array}{l}\text { Self- } \\
\text { rating } \\
\text { Correl } \\
\text { ation } \\
\text { for } \\
\text { Item } \\
\text { Pair }\end{array}$ \\
\hline $1(\mathrm{~N})$ & 2.81 & 1.14 & -1.30 & 0.76 & 0.74 & 3.87 & 0.84 & -0.63 & 0.65 & 0.55 & 0.67 & 0.50 \\
\hline $2(\mathrm{~N})$ & 2.45 & 1.12 & -1.53 & 0.71 & 0.70 & 3.89 & 0.84 & -0.25 & 0.66 & 0.54 & 1.28 & 0.52 \\
\hline $3(\mathrm{~N})$ & 2.60 & 1.09 & -1.76 & 0.78 & 0.75 & 3.74 & 0.90 & -0.87 & 0.68 & 0.57 & 0.89 & 0.57 \\
\hline $4(\mathrm{~N})$ & 2.98 & 1.16 & -1.39 & 0.75 & 0.61 & 3.74 & 0.98 & 0.47 & 0.64 & 0.44 & 0.92 & 0.51 \\
\hline $5(\mathrm{~N})$ & 3.01 & 1.25 & -1.40 & 0.70 & 0.54 & 3.60 & 1.08 & -0.97 & 0.63 & 0.43 & 0.43 & 0.60 \\
\hline $6(N)$ & 2.56 & 1.03 & 1.42 & 0.53 & 0.44 & 2.35 & 0.96 & 0.44 & 0.27 & 0.17 & 0.98 & 0.29 \\
\hline $7(\mathrm{~N})$ & 2.77 & 1.07 & 0.79 & 0.60 & 0.43 & 2.35 & 0.93 & 0.13 & 0.53 & 0.44 & 0.66 & 0.46 \\
\hline $8(\mathrm{~N})$ & 3.51 & 1.01 & 2.25 & 0.64 & 0.67 & 3.12 & 1.05 & 1.26 & 0.47 & 0.40 & 0.99 & 0.53 \\
\hline $9(\mathrm{~N})$ & 2.77 & 1.06 & 1.37 & 0.69 & 0.49 & 2.80 & 0.99 & -1.06 & 0.32 & 0.16 & 0.31 & 0.24 \\
\hline $10(\mathrm{~N})$ & 3.10 & 0.96 & 0.94 & 0.58 & 0.61 & 2.85 & 0.99 & 0.10 & 0.44 & 0.42 & 0.84 & 0.61 \\
\hline $11(\mathrm{E})$ & 3.56 & 0.92 & 2.04 & 0.56 & 0.54 & 2.90 & 1.15 & 0.44 & 0.25 & 0.09 & 1.60 & 0.17 \\
\hline $12(\mathrm{E})$ & 3.42 & 1.02 & 2.15 & 0.73 & 0.65 & 3.29 & 1.03 & 1.90 & 0.55 & 0.38 & 0.25 & 0.50 \\
\hline $13(\mathrm{E})$ & 3.48 & 1.04 & 2.05 & 0.73 & 0.67 & 2.87 & 1.11 & -1.09 & 0.36 & 0.34 & 0.96 & 0.46 \\
\hline $14(\mathrm{E})$ & 2.58 & 1.03 & 0.92 & 0.78 & 0.65 & 2.46 & 1.07 & 0.00 & 0.76 & 0.63 & 0.92 & 0.74 \\
\hline $15(\mathrm{E})$ & 3.19 & 0.98 & 1.15 & 0.67 & 0.58 & 2.74 & 1.12 & 0.08 & 0.71 & 0.60 & 1.07 & 0.41 \\
\hline $16(\mathrm{E})$ & 2.21 & 0.94 & -1.41 & 0.61 & 0.53 & 2.73 & 1.02 & -0.35 & 0.58 & 0.41 & 1.06 & 0.39 \\
\hline $17(\mathrm{E})$ & 3.03 & 1.04 & -0.68 & 0.74 & 0.71 & 3.45 & 1.02 & -0.43 & 0.72 & 0.59 & 0.25 & 0.65 \\
\hline 18 (E) & 2.25 & 1.01 & -1.75 & 0.39 & 0.42 & 2.94 & 1.15 & 0.57 & 0.11 & 0.15 & 1.18 & 0.31 \\
\hline 19 (E) & 3.48 & 1.05 & 0.56 & 0.64 & 0.52 & 3.43 & 1.03 & 0.36 & 0.71 & 0.61 & 0.20 & 0.72 \\
\hline 20 (E) & 2.57 & 1.15 & -0.98 & 0.77 & 0.63 & 3.69 & 0.88 & 0.12 & 0.64 & 0.51 & 0.86 & 0.48 \\
\hline $21(\mathrm{O})$ & 3.79 & 1.01 & 1.18 & 0.79 & 0.68 & 3.20 & 1.06 & 0.25 & 0.56 & 0.38 & 0.93 & 0.45 \\
\hline $22(0)$ & 3.67 & 1.04 & 1.12 & 0.54 & 0.43 & 3.90 & 0.96 & 0.54 & 0.31 & 0.28 & 0.58 & 0.46 \\
\hline $23(\mathrm{O})$ & 3.24 & 0.93 & 0.26 & 0.40 & 0.34 & 3.26 & 0.94 & 0.61 & 0.38 & 0.34 & -0.35 & 0.82 \\
\hline $24(0)$ & 3.31 & 0.89 & 1.52 & 0.21 & 0.20 & 3.03 & 0.91 & 0.37 & 0.51 & 0.41 & 1.15 & 0.17 \\
\hline $25(\mathrm{O})$ & 4.24 & 0.59 & 2.28 & 0.48 & 0.38 & 3.79 & 0.82 & 1.25 & 0.45 & 0.32 & 1.03 & 0.42 \\
\hline $26(\mathrm{O})$ & 2.14 & 0.83 & -0.75 & 0.70 & 0.57 & 2.98 & 0.91 & 0.36 & 0.67 & 0.52 & 0.39 & 0.48 \\
\hline $27(\mathrm{O})$ & 1.97 & 0.96 & -1.15 & 0.82 & 0.69 & 3.14 & 1.06 & 0.00 & 0.69 & 0.51 & 1.15 & 0.52 \\
\hline $28(\mathrm{O})$ & 2.28 & 1.03 & -0.82 & 0.66 & 0.53 & 3.04 & 0.98 & 0.37 & 0.51 & 0.29 & 0.45 & 0.29 \\
\hline $29(\mathrm{O})$ & 2.40 & 1.17 & -0.25 & 0.75 & 0.61 & 3.42 & 0.97 & 0.71 & 0.59 & 0.40 & -0.46 & 0.48 \\
\hline $30(\mathrm{O})$ & 2.45 & 0.92 & -0.41 & 0.43 & 0.37 & 2.57 & 0.89 & -0.67 & 0.41 & 0.33 & -0.26 & 0.59 \\
\hline 31 (A) & 3.58 & \begin{tabular}{c|}
0.90 \\
\end{tabular} & 1.86 & $\mathbf{0 . 5 3}$ & 0.41 & 2.37 & 0.83 & 1.00 & 0.46 & 0.30 & 0.86 & 0.19 \\
\hline $32(\mathrm{~A})$ & 3.57 & 0.82 & 1.94 & 0.57 & 0.46 & 2.98 & 1.02 & 1.68 & 0.51 & 0.28 & 0.26 & 0.46 \\
\hline $33(\mathrm{~A})$ & 4.42 & 0.61 & 2.81 & 0.61 & 0.47 & 3.36 & 0.95 & 1.77 & 0.61 & 0.42 & 1.04 & 0.32 \\
\hline 34 (A) & 3.99 & 0.73 & 2.41 & 0.60 & 0.46 & 3.39 & 0.94 & 1.90 & 0.59 & 0.37 & 0.51 & 0.50 \\
\hline 35 (A) & 3.92 & 0.71 & 2.33 & 0.38 & 0.31 & 3.40 & 0.96 & 0.43 & 0.43 & 0.36 & 1.90 & 0.13 \\
\hline 36 (A) & 2.87 & 1.12 & -0.99 & 0.60 & 0.46 & 3.55 & 1.03 & 0.84 & 0.33 & 0.28 & 0.15 & 0.36 \\
\hline 37 (A) & 1.68 & 0.84 & -2.75 & 0.68 & 0.53 & 2.67 & 1.04 & -1.59 & 0.46 & 0.39 & 1.16 & 0.29 \\
\hline 38 (A) & 3.28 & 1.04 & -1.32 & 0.45 & 0.37 & 3.50 & 0.97 & -0.73 & 0.44 & 0.31 & 0.59 & 0.63 \\
\hline 39 (A) & 2.25 & 0.98 & -2.14 & 0.59 & 0.45 & 2.82 & 1.02 & -1.06 & 0.61 & 0.47 & 1.08 & 0.39 \\
\hline 40 (A) & 2.05 & 0.98 & -2.44 & 0.66 & 0.54 & 3.22 & 1.09 & -0.45 & 0.44 & 0.43 & 1.99 & 0.27 \\
\hline $41(\mathrm{C})$ & 3.18 & 1.00 & 1.58 & 0.66 & 0.53 & 3.48 & 1.00 & 0.04 & 0.22 & 0.14 & 1.54 & 0.19 \\
\hline 42 (C) & 3.98 & 0.76 & 1.53 & 0.61 & 0.36 & 3.17 & 0.96 & 0.62 & 0.55 & 0.37 & 0.91 & 0.37 \\
\hline 43 (C) & 2.81 & 1.07 & 1.30 & 0.55 & 0.47 & 2.67 & 1.07 & 1.34 & 0.32 & 0.26 & -0.04 & 0.69 \\
\hline 44 (C) & 3.81 & 0.67 & 2.01 & 0.69 & 0.58 & 3.54 & 0.98 & 0.65 & 0.34 & 0.28 & 1.36 & 0.22 \\
\hline $45(\mathrm{C})$ & 3.56 & 0.87 & 1.57 & 0.63 & 0.48 & 3.00 & 0.95 & 1.28 & 0.47 & 0.38 & 0.29 & 0.56 \\
\hline $46(\mathrm{C})$ & 3.28 & 1.12 & -1.42 & 0.59 & 0.61 & 3.97 & 0.75 & 0.24 & 0.37 & 0.23 & 1.18 & 0.41 \\
\hline 47 (C) & 2.93 & 1.13 & -1.39 & 0.62 & 0.61 & 3.31 & 0.90 & 0.24 & 0.46 & 0.27 & 1.15 & 0.37 \\
\hline 48 (C) & 2.51 & 1.06 & -1.43 & 0.69 & 0.55 & 2.82 & 1.11 & -0.60 & 0.45 & 0.23 & 0.83 & 0.35 \\
\hline 49 (C) & 2.28 & 0.90 & -1.61 & 0.68 & 0.63 & 3.20 & 1.02 & -1.06 & 0.59 & 0.38 & 0.55 & 0.37 \\
\hline $50(\mathrm{C})$ & 2.31 & 0.88 & -2.10 & 0.64 & 0.55 & 2.59 & 0.94 & -1.06 & 0.58 & 0.38 & 1.04 & 0.30 \\
\hline
\end{tabular}

Note. $N=687$ for self-rating, factor loading, corrected item-total correlation, and item pair correlations. $N=63$ to 73 for social desirability. Mean self-ratings and social desirability ratings are based on raw scores-negative keyed items have not been reversed. Factor loadings are from principal component analysis using promax rotation with Kaiser normalization. Lines in bold are item pairs that were poorest. $\mathrm{N}=$ neuroticism, $\mathrm{E}=$ extraversion, $\mathrm{O}=$ openness, $\mathrm{A}=$ agreeableness, $\mathrm{C}$ 
$=$ conscientiousness. Mean social desirability is centered at zero, which was the neutral midpoint of 4 on a 1 to 7 social desirability scale.

\section{Table S3}

Factor Correlations and Descriptive Statistics for Standard IPIP NEO and LEFFI for Pilot Study

\begin{tabular}{|c|c|c|c|c|c|c|c|c|c|c|}
\hline Factor & 1 & 2 & 3 & 4 & 5 & 6 & 7 & 8 & 9 & 10 \\
\hline \multicolumn{11}{|l|}{ Standard IPIP NEO } \\
\hline \multicolumn{11}{|l|}{ 1. Neuroticism } \\
\hline 2. Extraversion & -.32 & & & & & & & & & \\
\hline 3. Openness & .03 & .10 & & & & & & & & \\
\hline 4. Agreeableness & -.28 & .11 & .12 & & & & & & & \\
\hline 5. Conscientiousness & -.45 & .12 & -.03 & .26 & & & & & & \\
\hline \multicolumn{11}{|l|}{ Neutralized (LEFFI) } \\
\hline 6. Neuroticism & .78 & -.25 & .10 & -.13 & -.36 & & & & & \\
\hline 7. Extraversion & -.23 & .84 & .09 & -.08 & .04 & -.22 & & & & \\
\hline 8. Openness & .14 & .02 & .78 & .05 & -.07 & .15 & .06 & & & \\
\hline 9. Agreeableness & -.14 & -.03 & -.02 & .69 & .15 & -.06 & -.20 & -.02 & & \\
\hline 10. Conscientiousness & -.15 & -.04 & -.13 & .17 & .68 & -.12 & -.12 & -.08 & .16 & \\
\hline \multicolumn{11}{|l|}{ Descriptive Statistics } \\
\hline$M$ & 2.81 & 3.17 & 3.75 & 3.83 & 3.42 & 3.56 & 2.76 & 3.14 & 3.12 & 2.91 \\
\hline$S D$ & .80 & .74 & .62 & .50 & .61 & .59 & .68 & .53 & .56 & .49 \\
\hline Cronbach's $\alpha$ & .87 & .86 & .81 & .73 & .80 & .78 & .81 & .68 & .68 & .61 \\
\hline
\end{tabular}

Note. $N=687$. All factors for both measures use 8 items, with two poorest items (bold in Table S2) removed. Correlations between same-factor standard and neutralized scales are italicized in lower left diagonal. LEFFI = Less Evaluative Five Factor Inventory.

$p<0.05$ in bold. 
Table S4

Criterion Descriptive Statistics and Correlations with Big Five Personality for Pilot Study

\begin{tabular}{|c|c|c|c|c|c|c|c|c|c|c|c|c|c|c|}
\hline \multirow[t]{2}{*}{ Criterion } & \multirow[t]{2}{*}{$M$} & \multirow[t]{2}{*}{$S D$} & \multicolumn{2}{|c|}{$\mathrm{N}$} & \multicolumn{2}{|c|}{$\mathrm{E}$} & \multicolumn{2}{|c|}{$\mathrm{O}$} & \multicolumn{2}{|c|}{ A } & \multicolumn{2}{|c|}{$\mathrm{C}$} & \multirow{2}{*}{$\begin{array}{c}\operatorname{Adj} R \\
\text { St }\end{array}$} & \multirow{2}{*}{$\begin{array}{l}\operatorname{Adj} R \\
\mathrm{Ne}\end{array}$} \\
\hline & & & St & $\mathrm{Ne}$ & St & $\mathrm{Ne}$ & St & $\mathrm{Ne}$ & St & $\mathrm{Ne}$ & St & $\mathrm{Ne}$ & & \\
\hline University Grade & 71.4 & 9.3 & $-.15_{\mathrm{aaa}}$ & -.01 & .02 & .01 & .11 & .08 & .05 & -.03 & .26 aaa & .14 & $.28_{\text {aaa }}$ & .15 \\
\hline Smoker & .12 & .33 & .04 & .02 & .16 & .16 & .11 & .13 & -.05 & -.08 & -.04 & .00 & .19 & .19 \\
\hline $\begin{array}{l}\text { Alcohol } \\
\text { Consumption }\end{array}$ & 2.51 & 1.07 & -.01 & .01 & .18 & .18 & .03 & .01 & .00 & $-.08 b$ & -.10 & -.09 & .20 & .18 \\
\hline Exercise Frequency & 2.88 & 2.16 & -.16 & -.15 & .10 & .07 & -.06 & -.09 & .06 & .09 & .23 & .19 & .24 & .24 \\
\hline Get-up Lateness & 9:11am & $99 \mathrm{~m}$ & $.23_{\text {aaa }}$ & .14 & $-.09_{\text {aаa }}$ & -.01 & .00 & .03 & -.17 & -.12 & $-.28 \mathrm{aaa}$ & -.16 & $.31_{\text {aa }}$ & .20 \\
\hline Donated Blood & .13 & & -.08 & -.07 & .04 & .02 & .04 & $.10_{\mathrm{b}}$ & .04 & .05 & .00 & -.04 & .06 & .12 \\
\hline $\begin{array}{l}\text { Dental Brushing } \\
\text { Frequency }\end{array}$ & 4.37 & 1.04 & -.10 & -.08 & .05 & .02 & -.01 & -.02 & .08 & .04 & .16 & .10 & .14 & .08 \\
\hline $\begin{array}{l}\text { Dental Flossing } \\
\text { Frequency }\end{array}$ & 2.55 & 1.86 & .02 & -.02 & -.05 & -.05 & .04 & .06 & .02 & .01 & .08 & .06 & .09 & .06 \\
\hline Has Tattoo & .36 & & .08 & .06 & .05 & .05 & .13 & .17 & .01 & -.06 & -.01 & .01 & .14 & .16 \\
\hline Played Instrument & .22 & & .04 & -.01 & -.02 & -.01 & .15 & .14 & -.01 & .00 & -.02 & -.02 & .13 & .11 \\
\hline $\begin{array}{l}\text { Attended Place of } \\
\text { Religious Worship }\end{array}$ & 1.74 & 1.07 & -.08 & -.12 & .02 & -.02 & -.10 & -.13 & .10 & .12 & .05 & .05 & .13 & .18 \\
\hline Made Bet & .23 & & -.01 & -.02 & .06 & .04 & -.04 & $-.09 \mathrm{~b}$ & -.01 & -.05 & .03 & .02 & .00 & .08 \\
\hline Bungy Jumped & .07 & & -.05 & -.05 & .07 & .08 & .08 & .06 & .02 & -.03 & .09 & .03 & .10 & .08 \\
\hline Sky Dived & .11 & & -.03 & -.05 & .03 & .05 & -.01 & -.03 & .02 & .04 & .02 & -.03 & .00 & .03 \\
\hline $\begin{array}{l}\text { Attended Heavy } \\
\text { Metal }\end{array}$ & .28 & & .03 & .04 & .04 & .04 & .22 & .23 & -.02 & -.01 & -.07 & -.05 & .22 & .21 \\
\hline Attended Ballet & .39 & & -.06 & -.03 & .05 & .03 & .19 & .15 & .06 & .05 & $.10_{\mathrm{a}}$ & .02 & .20 & .15 \\
\hline $\begin{array}{l}\text { Has Motorbike } \\
\text { License }\end{array}$ & .07 & & -.05 & -.07 & .00 & .04 & .02 & .03 & -.01 & $-.10 \mathrm{bb}$ & .06 & -.04 & .00 & .10 \\
\hline Shot Gun & .33 & & -.11 & -.08 & .08 & .09 & .02 & -.01 & -.01 & -.03 & .04 & -.04 & .09 & .08 \\
\hline Attended Football & .84 & & $-.07_{\mathrm{aa}}$ & -.01 & .14 & .11 & -.09 & -.10 & .03 & .02 & .08 & .06 & .16 & .15 \\
\hline Publicly Protested & .27 & & .01 & .00 & .02 & .03 & .35 & .36 & .00 & $-.08 b$ & -.05 & -.11 & .34 & .38 \\
\hline Can Touch Type & .83 & & -.01 & -.01 & .06 & .02 & .01 & .00 & .02 & .03 & .06 & .04 & .00 & .00 \\
\hline Female $^{c}$ & .82 & & .14 & .17 & .01 & -.03 & -.05 & .01 & .12 & .11 & .00 & .01 & .22 & .19 \\
\hline Age & 25.2 & 7.5 & $-.16 a$ & -.10 & .01 & -.01 & .16 & .14 & $.12_{\text {aаa }}$ & .00 & .13 aaa & -.01 & .24 & .17 \\
\hline $\begin{array}{l}\text { Mean of absolute } \\
\text { correlations }\end{array}$ & & & .07 & .06 & .06 & .05 & .09 & .09 & .04 & .05 & .08 & .06 & .15 & .14 \\
\hline
\end{tabular}

Note. $N=687$. All factors use 8 items. $\mathrm{N}=$ neuroticism, $\mathrm{E}=$ extraversion, $\mathrm{O}=$ openness, $\mathrm{A}=$ agreeableness, $\mathrm{C}=$ conscientiousness. $\mathrm{St}=$ Standard; $\mathrm{Ne}=$ Neutralized (LEFFI).

a Standard measure correlation is higher than neutralized measure, $p<.05$; b neutralized measure correlation is higher than standard measure, $p<.05$; aa Standard measure correlation is higher than neutralized measure, $p<.01$; bb neutralized measure correlation is higher than standard measure, $p<$ .01 ; aa Standard measure correlation is higher than neutralized measure, $p<.001$; bb neutralized measure correlation is higher than standard measure, $p<.001$, based on Steiger's $\mathrm{z}$ test. ${ }^{\mathrm{c}}$ Female was coded $0=$ male, $1=$ female .

For bivariate correlations, $r \geq .08, p<.05 ; r \geq .10, p<.01 . r \geq .13, p<.001$ are in bold. Significant adjusted multiple R's at $p<.05$ are in bold.

Two additional criteria were excluded due to large amounts of missing data (ranking in final year of high school) or lack of variability (almost all participants had baked a cake). 


\section{Main Study}

In the main study $(n=3,164)$, we replaced poor evaluatively neutralized items, based on results from the pilot study. All neutralized items are listed in Table A2 of the main article appendix. We again evaluated the success of neutralized item creation and quality of items by analyzing mean and standard deviation of selfratings, mean evaluativeness (with sign included to indicate whether it was desirable or undesirable), factor loading, corrected item-total correlation, difference between absolute evaluativeness of standard and neutral item pair, and correlation between standard and neutral item pair. Table S5 shows these results. Note, for ease of interpretation in Table S5, mean self-ratings and evaluativeness ratings are based on raw scores - negative keyed items have not been reversed.

Correlation between item social desirability (appropriate items reversed and neuroticism reversed) and item evaluativeness ( $n=100$ items) was high for both the standard measure, $r(48)=.98, p<.001,95 \%$ CI $[.96, .99]$, and neutralized measure, $r(48)=.95, p<.001$. Each pair of standard and neutralized items had a similarity rating, either from the initial pilot of items $(n=10)$ or from the later testing of similarity of what were to become the 24 new neutralized items and their standard counterparts $(n=25)$. These sample sizes were different, but correlation between item pair similarity and item social desirability was $r(48)=.11, p=.444,95 \% \mathrm{CI}$ $[-.17, .38]$ for standard items and $r(48)=.42, p=.002,95 \%$ CI $[.16, .63]$ for neutralized items. Correlation between item pair similarity and item evaluativeness was $r(48)=.17, p=.251,95 \%$ CI $[-.11, .43]$ for standard items and $r(48)=.46, p$ $=.001,95 \%$ CI $[.21, .65]$ for neutralized items. 
Table S5

Main Study Standard and Neutralized (LEFFI) Item Descriptives and Psychometrics

\begin{tabular}{|c|c|c|c|c|c|c|c|c|c|c|c|c|}
\hline & & & Standard It & & & & & eutralized Iter & & & & \\
\hline $\begin{array}{l}\text { Item } \\
\text { Number }\end{array}$ & $\begin{array}{l}\text { Mean } \\
\text { Self- } \\
\text { rating }\end{array}$ & $\begin{array}{l}\text { SD } \\
\text { Self- } \\
\text { rating }\end{array}$ & $\begin{array}{l}\text { Evaluative } \\
\text { ness }\end{array}$ & $\begin{array}{l}\text { Factor } \\
\text { Loading }\end{array}$ & $\begin{array}{l}\text { Corrected } \\
\text { Item- } \\
\text { Total } \\
\text { Correlati } \\
\text { on }\end{array}$ & $\begin{array}{l}\text { Mean Self- } \\
\text { rating }\end{array}$ & $\begin{array}{l}\text { SD Self- } \\
\text { rating }\end{array}$ & $\begin{array}{l}\text { Evaluative } \\
\text { ness }\end{array}$ & $\begin{array}{l}\text { Factor } \\
\text { Loading }\end{array}$ & $\begin{array}{l}\text { Corrected } \\
\text { Item-Total } \\
\text { Correlatio } \\
n\end{array}$ & $\begin{array}{l}\text { Standard } \\
\text { Social Des } \\
\text { (abs)- } \\
\text { Neutral } \\
\text { Social Des } \\
\text { (abs) }\end{array}$ & $\begin{array}{l}\text { Self- } \\
\text { rating } \\
\text { Correl } \\
\text { ation } \\
\text { for } \\
\text { Item } \\
\text { Pair } \\
\end{array}$ \\
\hline $1(\mathrm{~N})$ & 2.87 & 1.12 & -1.30 & 0.77 & .73 & 3.86 & 0.81 & -0.63 & 0.64 & .56 & 0.67 & 0.46 \\
\hline $2(\mathrm{~N})$ & 2.47 & 1.11 & -1.53 & 0.68 & .67 & 3.82 & 0.87 & -0.25 & 0.57 & .52 & 1.28 & 0.50 \\
\hline $3(\mathrm{~N})$ & 2.66 & 1.08 & -1.76 & 0.75 & .72 & 3.71 & 0.91 & -0.87 & 0.65 & .59 & 0.89 & 0.53 \\
\hline $4(\mathrm{~N})$ & 3.07 & 1.14 & -2.03 & 0.75 & .59 & 3.57 & 0.94 & -1.31 & 0.69 & .51 & 0.72 & 0.41 \\
\hline $5(\mathrm{~N})$ & 3.19 & 1.22 & -1.40 & 0.74 & .54 & 3.58 & 1.05 & -0.97 & 0.68 & .46 & 0.43 & 0.53 \\
\hline $6(\mathrm{~N})$ & 2.58 & 1.02 & 2.22 & 0.58 & .45 & 2.67 & 0.97 & 1.64 & 0.57 & .43 & 0.58 & 0.43 \\
\hline $7(\mathrm{~N})$ & 2.76 & 1.04 & 0.79 & 0.52 & .42 & 2.41 & 0.93 & 0.13 & 0.52 & .44 & 0.66 & 0.41 \\
\hline $8(\mathrm{~N})$ & 3.56 & 1.01 & 2.32 & 0.63 & .63 & 3.26 & 1.01 & 2.01 & 0.49 & .57 & 0.31 & 0.67 \\
\hline $9(\mathrm{~N})$ & 2.82 & 1.08 & 1.81 & 0.70 & .52 & 2.78 & 1.03 & 1.47 & 0.66 & .50 & 0.34 & 0.56 \\
\hline $10(\mathrm{~N})$ & 3.22 & 0.94 & 0.94 & 0.52 & .57 & 2.85 & 1.00 & 0.10 & 0.40 & .47 & 0.84 & 0.56 \\
\hline $11(\mathrm{E})$ & 3.52 & 0.95 & 2.48 & 0.63 & .60 & 3.07 & 1.05 & 1.63 & 0.63 & .48 & 0.85 & 0.47 \\
\hline $12(\mathrm{E})$ & 3.42 & 1.05 & 2.15 & 0.72 & .65 & 3.21 & 1.02 & 1.90 & 0.65 & .51 & 0.25 & 0.49 \\
\hline $13(\mathrm{E})$ & 3.56 & 1.01 & 2.37 & 0.69 & .65 & 2.83 & 1.08 & 1.58 & 0.56 & .50 & 0.79 & 0.47 \\
\hline $14(\mathrm{E})$ & 2.68 & 1.06 & 0.92 & 0.79 & .63 & 2.41 & 1.04 & 0.00 & 0.77 & .65 & 0.92 & 0.67 \\
\hline $15(\mathrm{E})$ & 3.21 & 0.95 & 1.15 & 0.67 & .58 & 2.82 & 1.07 & 0.08 & 0.74 & .62 & 1.07 & 0.39 \\
\hline $16(\mathrm{E})$ & 2.26 & 0.94 & -1.41 & 0.58 & .51 & 2.87 & 1.03 & -0.35 & 0.45 & .40 & 1.06 & 0.39 \\
\hline $17(\mathrm{E})$ & 3.09 & 1.02 & -0.68 & 0.76 & .70 & 3.55 & 0.95 & -0.43 & 0.67 & .61 & 0.25 & 0.55 \\
\hline $18(\mathrm{E})$ & 2.29 & 1.02 & -1.35 & 0.39 & .44 & 2.59 & 1.06 & -1.09 & 0.35 & .34 & 0.26 & 0.67 \\
\hline $19(\mathrm{E})$ & 3.48 & 1.04 & 0.56 & 0.63 & .51 & 3.43 & 0.98 & 0.36 & 0.70 & .62 & 0.20 & 0.63 \\
\hline $20(\mathrm{E})$ & 2.55 & 1.11 & -0.98 & 0.77 & .64 & 3.73 & 0.85 & 0.12 & 0.56 & .50 & 0.86 & 0.39 \\
\hline $21(\mathrm{O})$ & 3.93 & 0.92 & 1.18 & 0.78 & .62 & 3.31 & 1.02 & 0.25 & 0.51 & .38 & 0.93 & 0.41 \\
\hline $22(\mathrm{O})$ & 3.88 & 0.97 & 1.27 & 0.48 & .36 & 3.49 & 1.07 & 0.97 & 0.45 & .34 & 0.29 & 0.70 \\
\hline $23(\mathrm{O})$ & 3.36 & 1.02 & 0.26 & 0.35 & .31 & 3.33 & 0.98 & 0.61 & 0.39 & .32 & -0.35 & 0.79 \\
\hline $24(\mathrm{O})$ & 3.49 & 0.89 & 1.52 & 0.26 & .24 & 3.10 & 0.91 & 0.37 & 0.54 & .44 & 1.15 & 0.14 \\
\hline $25(\mathrm{O})$ & 4.28 & 0.60 & 2.51 & 0.44 & .35 & 3.89 & 0.72 & 1.73 & 0.53 & .41 & 0.79 & 0.35 \\
\hline $26(\mathrm{O})$ & 2.06 & 0.84 & -0.75 & 0.65 & .49 & 3.00 & 0.92 & 0.36 & 0.69 & .52 & 0.39 & 0.41 \\
\hline $27(\mathrm{O})$ & 1.92 & 0.95 & -1.15 & 0.75 & .58 & 3.08 & 1.04 & 0.00 & 0.62 & .48 & 1.15 & 0.50 \\
\hline $28(\mathrm{O})$ & 2.11 & 0.99 & -0.70 & 0.58 & .45 & 2.32 & 1.01 & -0.67 & 0.66 & .48 & 0.03 & 0.62 \\
\hline $29(\mathrm{O})$ & 2.36 & 1.14 & -0.25 & 0.70 & .51 & 3.37 & 0.97 & 0.71 & 0.48 & .32 & -0.46 & 0.37 \\
\hline $30(\mathrm{O})$ & 2.35 & 1.01 & -0.41 & 0.36 & .31 & 2.44 & 1.02 & -0.47 & 0.41 & .31 & -0.06 & 0.74 \\
\hline $31(\mathrm{~A})$ & 3.59 & 0.91 & 2.05 & 0.57 & .39 & 3.33 & 0.94 & 1.86 & 0.60 & .42 & 0.19 & 0.50 \\
\hline 32 (A) & 3.65 & 0.84 & 2.05 & 0.54 & .42 & 3.19 & 1.13 & 0.38 & 0.58 & .38 & 1.68 & 0.42 \\
\hline 33 (A) & 4.49 & 0.59 & 2.81 & 0.58 & .39 & 3.28 & 0.97 & 1.77 & 0.63 & .46 & 1.04 & 0.22 \\
\hline 34 (A) & 4.16 & 0.74 & 2.41 & 0.57 & .38 & 3.32 & 0.90 & 1.90 & 0.59 & .42 & 0.51 & 0.37 \\
\hline 35 (A) & 3.94 & 0.73 & 2.33 & 0.41 & .31 & 3.45 & 0.98 & 0.43 & 0.48 & .29 & 1.90 & 0.13 \\
\hline 36 (A) & 2.95 & 1.13 & -1.80 & 0.53 & .39 & 3.44 & 1.05 & -0.96 & 0.47 & .42 & 0.84 & 0.33 \\
\hline 37 (A) & 1.67 & 0.80 & -2.67 & 0.65 & .51 & 2.69 & 1.06 & -2.28 & 0.50 & .46 & 0.38 & 0.40 \\
\hline 38 (A) & 3.24 & 1.07 & -1.32 & 0.39 & .37 & 3.52 & 0.94 & -0.73 & 0.38 & .36 & 0.59 & 0.56 \\
\hline 39 (A) & 2.27 & 0.99 & -2.14 & 0.53 & .43 & 2.85 & 1.02 & -1.06 & 0.58 & .49 & 1.08 & 0.32 \\
\hline $40(\mathrm{~A})$ & 2.00 & 0.99 & -2.76 & 0.66 & .54 & 2.73 & 1.09 & -1.95 & 0.51 & .47 & 0.81 & 0.42 \\
\hline $41(\mathrm{C})$ & 3.33 & 0.97 & 2.48 & 0.65 & .50 & 3.22 & 1.00 & 2.04 & 0.67 & .52 & 0.44 & 0.61 \\
\hline $42(\mathrm{C})$ & 4.06 & 0.80 & 1.53 & 0.49 & .28 & 3.22 & 0.96 & 0.62 & 0.53 & .32 & 0.91 & 0.30 \\
\hline 43 (C) & 2.95 & 1.09 & 2.20 & 0.58 & .47 & 2.71 & 1.01 & 1.75 & 0.58 & .48 & 0.45 & 0.46 \\
\hline $44(\mathrm{C})$ & 3.79 & 0.75 & 2.40 & 0.69 & .58 & 3.26 & 0.92 & 2.26 & 0.69 & .59 & 0.14 & 0.52 \\
\hline 45 (C) & 3.62 & 0.88 & 2.19 & 0.64 & .52 & 2.96 & 0.94 & 1.04 & 0.66 & .51 & 1.15 & 0.45 \\
\hline $46(\mathrm{C})$ & 3.11 & 1.12 & -2.17 & 0.67 & .63 & 3.80 & 0.87 & -1.39 & 0.57 & .50 & 0.78 & 0.57 \\
\hline $47(\mathrm{C})$ & 2.90 & 1.11 & -1.89 & 0.66 & .59 & 3.73 & 0.87 & -0.93 & 0.52 & .48 & 0.96 & 0.34 \\
\hline 48 (C) & 2.59 & 1.10 & -1.77 & 0.64 & .52 & 3.07 & 1.11 & -1.65 & 0.66 & .54 & 0.12 & 0.59 \\
\hline 49 (C) & 2.30 & 0.88 & -1.61 & 0.66 & .56 & 3.22 & 1.00 & -1.06 & 0.51 & .43 & 0.55 & 0.34 \\
\hline $50(\mathrm{C})$ & 2.24 & 0.91 & -2.34 & 0.59 & .50 & 2.98 & 1.03 & -1.99 & 0.64 & .52 & 0.35 & 0.42 \\
\hline
\end{tabular}

Note. $N=3,164$ for self-rating, factor loading, corrected item-total correlation, and item pair correlations. $N=64$ to 75 for social desirability of items. Factor loadings are from principal component analysis using promax rotation with Kaiser normalization. Mean self-ratings and social desirability ratings are based on raw scores - negative keyed items have not been reversed. $\mathrm{N}=$ neuroticism, $\mathrm{E}=$ extraversion, $\mathrm{O}=$ openness, $\mathrm{A}=$ agreeableness, $\mathrm{C}=$ conscientiousness. $\mathrm{LEFFI}=$ 
Neutralized Item Five Factor Inventory. Mean social desirability is centered at zero, which was the neutral midpoint of 4 on a 1 to 7 social desirability scale.

Principal component analysis was performed for both the standard items and the neutralized items. The results are shown in Table S6.

\section{Table S6}

Main Study Loadings from Principal Component Analysis of Standard and Neutralized (LEFFI) Items

\begin{tabular}{|c|c|c|c|c|c|c|c|c|c|c|}
\hline \multirow{2}{*}{$\begin{array}{c}\text { Item } \\
\text { Number }\end{array}$} & \multicolumn{5}{|c|}{ Standard } & \multicolumn{5}{|c|}{ Neutralized } \\
\hline & $\mathrm{N}$ & E & $\mathrm{O}$ & A & $\mathrm{C}$ & $\mathrm{N}$ & E & $\mathrm{O}$ & A & C \\
\hline $1(\mathrm{~N})$ & 0.77 & & & & & 0.64 & & & & \\
\hline $2(\mathrm{~N})$ & 0.68 & & & & & 0.57 & & & & \\
\hline $3(\mathrm{~N})$ & 0.75 & & & & & 0.65 & & & & \\
\hline $4(\mathrm{~N})$ & 0.75 & & & & & 0.69 & & & & \\
\hline $5(\mathrm{~N})$ & 0.74 & & & & & 0.68 & & & & \\
\hline $6(\mathrm{~N})$ & 0.58 & & & -0.25 & & 0.57 & & & & \\
\hline $7(\mathrm{~N})$ & 0.52 & & & & & 0.52 & & & & \\
\hline $8(\mathrm{~N})$ & 0.63 & & & & & 0.49 & -0.27 & & & \\
\hline $9(\mathrm{~N})$ & 0.70 & & & & & 0.66 & & & & 0.21 \\
\hline $10(\mathrm{~N})$ & 0.52 & -0.23 & & & & 0.40 & -0.27 & & & \\
\hline $11(\mathrm{E})$ & & 0.63 & & & & & 0.63 & & 0.28 & \\
\hline $12(\mathrm{E})$ & & 0.72 & & & & & 0.65 & & 0.29 & \\
\hline $13(\mathrm{E})$ & & 0.69 & & & & & 0.56 & & & \\
\hline $14(\mathrm{E})$ & & 0.79 & & & & & 0.77 & & & \\
\hline $15(\mathrm{E})$ & & 0.67 & & & & & 0.74 & & & \\
\hline $16(\mathrm{E})$ & & 0.58 & 0.22 & & & & 0.45 & & -0.31 & \\
\hline $17(\mathrm{E})$ & & 0.76 & & & & & 0.67 & & & \\
\hline $18(\mathrm{E})$ & & 0.39 & & & & & 0.35 & & & \\
\hline 19 (E) & & 0.63 & & & & & 0.70 & & & \\
\hline $20(\mathrm{E})$ & & 0.77 & & & & & 0.56 & & & \\
\hline $21(\mathrm{O})$ & & & 0.78 & & & & & 0.51 & & \\
\hline $22(\mathrm{O})$ & & 0.20 & 0.48 & & & & 0.26 & 0.45 & & \\
\hline $23(\mathrm{O})$ & & & 0.35 & & & & & 0.39 & & \\
\hline $24(\mathrm{O})$ & & 0.45 & 0.26 & & & & & 0.54 & & \\
\hline $25(\mathrm{O})$ & & & 0.44 & & & & & 0.53 & & \\
\hline $26(\mathrm{O})$ & & & 0.65 & & & & & 0.69 & & \\
\hline $27(\mathrm{O})$ & & & 0.75 & & & & & 0.62 & & \\
\hline $28(\mathrm{O})$ & & & 0.58 & & & & & 0.66 & & \\
\hline $29(\mathrm{O})$ & & & 0.70 & & & & -0.20 & 0.48 & & \\
\hline $30(\mathrm{O})$ & & & 0.36 & & & & & 0.41 & & \\
\hline $31(\mathrm{~A})$ & & & & 0.57 & & & & & 0.60 & \\
\hline 32 (A) & & & & 0.54 & & & & & 0.58 & \\
\hline 33 (A) & & & & 0.58 & & & & & 0.63 & \\
\hline 34 (A) & & & & 0.57 & & & & & 0.59 & \\
\hline 35 (A) & & 0.43 & & 0.41 & & & & & 0.48 & \\
\hline 36 (A) & & -0.30 & & 0.53 & & & & & 0.47 & \\
\hline 37 (A) & & & & 0.65 & & & -0.23 & & 0.50 & \\
\hline 38 (A) & -0.27 & & & 0.39 & & -0.21 & & & 0.38 & \\
\hline 39 (A) & & & & 0.53 & & & & & 0.58 & \\
\hline 40 (A) & & & & 0.66 & & & & & 0.51 & 0.21 \\
\hline $41(\mathrm{C})$ & & & & & 0.65 & & & & & 0.67 \\
\hline $42(\mathrm{C})$ & 0.26 & & & & 0.49 & 0.34 & & & & 0.53 \\
\hline $43(\mathrm{C})$ & & & & & 0.58 & & & & & 0.58 \\
\hline 44 (C) & & & & & 0.69 & & & & & 0.69 \\
\hline $45(\mathrm{C})$ & & & & & 0.64 & & & & & 0.66 \\
\hline $46(C)$ & & & & & 0.67 & -0.22 & & & & 0.57 \\
\hline 47 (C) & & & & & 0.66 & & & & & 0.52 \\
\hline $48(\mathrm{C})$ & & & & & 0.64 & & & & & 0.66 \\
\hline 49 (C) & & & & & 0.66 & & & & & 0.51 \\
\hline $50(\mathrm{C})$ & & & & & 0.59 & & & & & 0.64 \\
\hline
\end{tabular}




\subsection{Social Desirability of Criteria}

We also measured the social desirability of the self-report criteria, to examine the potential problem of socially desirable responding, to the evaluative content of both the personality items and the criteria, leading to common-method bias and artificially increasing the criterion validity of the more evaluative standard personality questionnaire. Social desirability of criteria was measured on the same 1 to 7 scale as was used to measure social desirability of personality items and the mean social desirabilities of the self-report criteria are shown in Table S7. The most evaluative criteria, with 1 to 7 mean social desirability scores shown in parentheses, were exercise frequency (6.24), dental brushing frequency (6.15), university grade (5.92), smoker (2.18), and alcohol consumption (2.31). Backstrom et al. (2014) took the mean criterion validity of each criterion across the Big Five scales and then calculated the relationship between mean validity and criterion social desirability. Although we have a much smaller number of self-report criteria with social desirability ratings $(n=14)$, inadequate to clearly assess correlations, when we perform this calculation the results were non-significant, but nonetheless very similar. The standard measure had a correlation of $r=-.11(p=.703)$ and the neutralized measure, $r=-.11(p=.716)$.

\section{Table S7}

\section{Criterion Descriptive Statistics}

\begin{tabular}{lcccc}
\hline \multicolumn{1}{c}{ Criterion } & $M$ & $S D$ & $\begin{array}{c}\text { Soc Des } \\
(1-7)\end{array}$ & Retest \\
& & & & \\
\hline Self-reported criteria & & & & \\
University Grade & 72.80 & 9.82 & 5.92 & .50 \\
Smoker & .09 & .287 & 2.18 & .46 \\
Alcohol Consumption & 2.39 & 1.02 & 2.31 & .71 \\
Exercise Frequency & 3.04 & 2.43 & 6.24 & .42 \\
Get-up Lateness & $9: 07 \mathrm{am}$ & $1.72 \mathrm{~h}$ & 3.87 & .58 \\
Donated Blood & .12 & .32 & 5.21 & .71 \\
Dental Brushing Frequency & 4.41 & 1.04 & 6.15 & .74 \\
Has Tattoo & .37 & .48 & 3.87 & .88 \\
Played Instrument & .26 & .44 & 5.01 & .77 \\
Attended Place of Religious Worship & 1.69 & 1.06 & 4.23 & .88 \\
Attended Heavy Metal & .22 & .41 & 4.03 & .79 \\
Attended Ballet & .40 & .49 & 4.64 & .87 \\
Attended Football & .82 & .39 & 4.59 & .83 \\
Publicly Protested & .25 & .43 & 4.04 & .67 \\
Female & .82 & .39 & & .95 \\
Age & 25.66 & 8.57 & & .94
\end{tabular}

Note. Retest period was 1 year, so many criteria results are likely to have actually changed for participants. Social Desirability $n=91$. Retest $n=125$ to 138 . 